\title{
Gas-particle interactions above a Dutch heathland: II. Concentrations and surface exchange fluxes of atmospheric particles
}

\author{
E. Nemitz ${ }^{1}$, M. A. Sutton ${ }^{1}$, G. P. Wyers ${ }^{2}$, R. P. Otjes ${ }^{2}$, M. G. Mennen ${ }^{3}$, E. M. van Putten ${ }^{3}$, and M. W. Gallagher \\ ${ }^{1}$ Atmospheric Sciences, Centre for Ecology and Hydrology (CEH), Edinburgh Research Station, Bush Estate, Penicuik, \\ Midlothian, EH26 0QB, UK \\ ${ }^{2}$ Energy research Centre of the Netherlands (ECN), Postbus 1, 1755 Petten ZG, The Netherlands \\ ${ }^{3}$ National Institute of Public Health and Environment (RIVM), Postbus 1, 3720 BA Bilthoven, The Netherlands \\ ${ }^{4}$ University of Manchester Institute of Science and Technology (UMIST), Physics Department, PO Box 88, Manchester, M60 \\ 1QD, UK
}

Received: 15 December 2003 - Published in Atmos. Chem. Phys. Discuss.: 15 March 2004

Revised: 11 June 2004 - Accepted: 14 June 2004 - Published: 2 July 2004

\begin{abstract}
Size-dependent particle number fluxes measured by eddy-covariance (EC) and continuous fluxes of ammonium $\left(\mathrm{NH}_{4}^{+}\right)$measured with the aerodynamic gradient method (AGM) are reported for a Dutch heathland. Daytime deposition velocities $\left(V_{d}\right)$ by EC with peak values of 5 to $10 \mathrm{~mm} \mathrm{~s}^{-1}$ increased with particle diameter $\left(d_{p}\right)$ over the range $0.1-0.5 \mu \mathrm{m}$, and are faster than predicted by current models. With a mean $V_{d}$ of $2.0 \mathrm{~mm} \mathrm{~s}^{-1}$ (daytime: 2.7; nighttime $0.8 \mathrm{~mm} \mathrm{~s}^{-1}$ ) $\mathrm{NH}_{4}^{+}$fluxes by AGM are overall in agreement with former measurements and $\mathrm{NH}_{4}^{+}-\mathrm{N}$ dry deposition amounts to $20 \%$ of the dry input of $\mathrm{NH}_{3}-\mathrm{N}$ over the measurement period. These surface exchange fluxes are analyzed together with simultaneous gas-phase flux measurements for indications of gas-particle interactions. On warm afternoons the apparent fluxes of acids and aerosol above the heathland showed several coinciding anomalies, all of which are consistent with $\mathrm{NH}_{4}^{+}$evaporation during deposition: (i) canopy resistances for $\mathrm{HNO}_{3}$ and $\mathrm{HCl}$ of up to $100 \mathrm{~s} \mathrm{~m}^{-1}$, (ii) simultaneous particle emission of small particles $\left(D_{p}<0.18 \mu \mathrm{m}\right)$ and deposition of larger particles $\left(D_{p}>0.18 \mu \mathrm{m}\right)$, (iii) $\mathrm{NH}_{4}^{+}$ deposition faster than derived from size-distributions and size-segregated EC particle fluxes. These observations coincide with the observations of (i) surface concentration products of $\mathrm{NH}_{3}$ and $\mathrm{HNO}_{3}$ well below the thermodynamic equilibrium value and (ii) Damköhler numbers that indicate chemical conversion to be sufficiently fast to modify exchange fluxes. The measurements imply a removal rate of volatile $\mathrm{NH}_{4}^{+}$of $3-30 \times 10^{-6} \mathrm{~s}^{-1}$ averaged over the $1 \mathrm{~km}$ boundary-layer, while $\mathrm{NH}_{3}$ deposition is underestimated by typically $20 \mathrm{ng} \mathrm{m}^{-2} \mathrm{~s}^{-1}(28 \%)$ and flux reversal may occur.
\end{abstract}

Correspondence to: E. Nemitz

(en@ceh.ac.uk)

\section{Introduction}

\subsection{Background}

The deposition of atmospheric aerosol particles can considerably contribute to the atmospheric inputs of pollutants such as nitrogen and sulphate compounds (Hanson and Lindberg, 1991; Wyers and Duyzer, 1997; Dammgen and Zimmerling, 2002; Sanz et al., 2002), in particular in dry and remote environments and over aerodynamically rough surfaces. The deposition of the aerosol components ammonium $\left(\mathrm{NH}_{4}^{+}\right)$, nitrate $\left(\mathrm{NO}_{3}^{-}\right)$, chloride $\left(\mathrm{Cl}^{-}\right)$and sulphate $\left(\mathrm{SO}_{4}^{2-}\right)$ contributes to acidification and eutrophication of ecosystems. Since in general particles deposit more slowly than reactive gases, they often dominate long-range transport and transboundary fluxes of air pollutants. Yet, the surface/atmosphere exchange of particles has been studied in less detail than their gaseous counterparts. This is partly due to difficulties in the application of micrometeorological techniques to particles: their deposition velocity $\left(V_{d}\right)$ is small, while vertical concentration gradients are weak and difficult to detect. In addition, there are no fast-response sensors for these aerosol chemical species that would enable the application of direct measurement techniques such as eddy-covariance (EC). However, the latter has been applied to infer size-dependent particle number fluxes using optical particle counters (e.g. Sievering, 1983, 1987; Gallagher et al., 1993; Gallagher et al., 1997; Nemitz et al., 2002).

Particles may be emitted by combustion processes, resuspended from soils and road surfaces and generated by frictional processes. Primary particle emissions from vegetation canopies are confined to biological aerosols such as spores and pollen. The slower deposition of particles if compared 
with gases has been derived by several theoretical approaches (Slinn, 1982; Peters and Eiden, 1992; Ruijgrok et al., 1997) and validated in wind tunnel studies (Chamberlain, 1966) as well as measurements above short vegetation (Nemitz et al., 2002). There is growing evidence, however, that deposition rates to forests may be much larger than previously assumed (Gallagher et al., 1997; Wyers and Duyzer, 1997; Garland, 2001).

As a further complication, measurements of the surface exchange of reactive compounds, both gases and aerosols, may be affected by chemical conversions (Fitzjarrald and Lenschow, 1983). For example, fluxes of nitrous oxide (NO) have to be corrected for the chemistry of the photochemical $\mathrm{NO}-\mathrm{NO}_{2}-\mathrm{O}_{3}$ triad. Similarly, for the accurate measurement of fluxes of ammonia $\left(\mathrm{NH}_{3}\right)$, nitric acid $\left(\mathrm{HNO}_{3}\right)$, hydrochloric acid $(\mathrm{HCl})$, sulphuric acid $\left(\mathrm{H}_{2} \mathrm{SO}_{4}\right)$ as well as their associated aerosol species $\left(\mathrm{NH}_{4}^{+}, \mathrm{NO}_{3}^{-}, \mathrm{Cl}^{-}, \mathrm{SO}_{4}^{2-}\right)$, the following reactions need to be considered:

$$
\begin{gathered}
\mathrm{NH}_{3}+\mathrm{HNO}_{3} \leftrightarrow \mathrm{NH}_{4} \mathrm{NO}_{3} \\
K_{e}\left(\mathrm{NH}_{4} \mathrm{NO}_{3}\right), \\
\mathrm{NH}_{3}+\mathrm{HCl} \leftrightarrow \mathrm{NH}_{4} \mathrm{Cl} \\
K_{e}\left(\mathrm{NH}_{4} \mathrm{Cl}\right),
\end{gathered}
$$

$$
\begin{aligned}
& \text { (2) } \mathrm{NH}_{3}+\mathrm{H}_{2} \mathrm{SO}_{4} \leftrightarrow \mathrm{NH}_{4} \mathrm{HSO}_{4},\left(\mathrm{NH}_{4}\right)_{2} \mathrm{SO}_{4} \\
& \quad K_{e}\left(\mathrm{NH}_{4} \mathrm{HSO}_{4}\right),
\end{aligned}
$$

where the $K_{e}$ are the dissociation constants of the associated ammonium salts. The vapour pressure above sulphate $\left(\mathrm{SO}_{4}^{2-}\right)$ aerosols is sufficiently small to consider Reaction (3) irreversible. It is therefore assumed that any sulphuric acid $\left(\mathrm{H}_{2} \mathrm{SO}_{4}\right)$ produced in the atmosphere, for example by oxidation of $\mathrm{SO}_{2}$ by $\mathrm{OH}$ radicals, is immediately neutralized by $\mathrm{NH}_{3}$ (Seinfeld and Pandis, 1997). By contrast, the reactions of Eqs. (1) and (2) can lead to either gas-to-particle conversion (gtpc) or aerosol evaporation; both processes are here commonly referred to as gas-particle interconversion (gpic). Despite its similarity to the $\mathrm{NO}-\mathrm{O}_{3}-\mathrm{NO}_{2}$ triad, gpic involving $\mathrm{NH}_{3}$ is more difficult to model. Whereas the reaction of $\mathrm{NO}$ with $\mathrm{O}_{3}$ is a homogenous gas-phase reaction with welldefined reaction rates and (photochemical) equilibrium state, the reaction mechanisms and time-scales of the (probably) inhomogeneous gpic are an issue of controversy in the literature.

1.2 Effects of gas-particle interconversion on surface exchange fluxes of gases and aerosols

The height $(z)$ dependence of the flux $\left(F_{\chi}\right)$ of a tracer $(\chi)$ for which there are chemical sources or sinks in the atmosphere, may be approximated by first-order relaxation towards equilibrium (Brost et al., 1988):

$\frac{d F_{\chi}}{d z}=Q_{\chi}=\frac{\chi-\chi_{e q}}{\tau_{c}}$ where $Q_{\chi}$ is the chemical source/sink term, $\chi$ is the actual concentration and $\chi_{e q}$ is the hypothetical concentration of $\chi$ if equilibrium were attained. $\tau_{c}$ is the chemical relaxation time-scale for the attainment of equilibrium (Wexler and Seinfeld, 1990). Thus flux divergence is a result of deviation from thermodynamic equilibrium, which in the atmosphere may have several causes (Nemitz, 1998):

a) Close to strong sources of $\mathrm{NH}_{3}, \mathrm{HNO}_{3}$ or $\mathrm{HCl}$ there is likely to be potential for aerosol formation.

b) Surface/atmosphere exchange leads to vertical gradients of both acidic gases and ammonia. As a result thermodynamic equilibrium may be restricted to a single height or not occur at all.

c) The equilibrium constant $\left(K_{e}\right)$ is a function of temperature and relative humidity (Pio and Harrison, 1987; Mozurkewich, 1993) and therefore changes with height.

If equilibration is sufficiently fast ( $\tau_{c}$ small) compared with the time-scale of turbulent diffusive transfer $\left(\tau_{d}\right)$, the concentration gradients, and therefore the fluxes, will be modified by the tendency to re-attain equilibrium. If gtpc affects the gradient, then micrometeorological techniques overestimate the deposition of the gases, compared with the true surface exchange flux, at the same time as they underestimate the deposition of the aerosol or even indicate apparent aerosol emission. By contrast, in the case of aerosol evaporation, measurements may derive unexpected small deposition rates or apparent emission of the gases as well as over-rapid deposition of the aerosol species.

Direct validation of the influence of the $\mathrm{NH}_{3}-\mathrm{NH}_{4}^{+}$equilibrium on surface exchange fluxes has so far proven difficult. Measurement approaches that derive the flux at a single height would be needed to detect vertical flux divergence directly. However, the implementation of eddy-covariance techniques for sticky gases such as $\mathrm{NH}_{3}$ and $\mathrm{HNO}_{3}$ and aerosols is difficult, while relaxed eddy accumulation techniques for $\mathrm{NH}_{3}$ are still insufficiently precise to resolve such flux divergence (Nemitz et al., 2001). It is much harder to derive evidence for gpic from measurements of vertical gradients of concentration (rather than of fluxes). Nevertheless, from simultaneous gradient measurements of $\mathrm{HNO}_{3}$ and $\mathrm{NH}_{3}$, Harrison et al. (1989) concluded that gpic effects are negligible, and this work has often been cited as a justification for the applicability of aerodynamic gradient techniques to $\mathrm{NH}_{3}$. However, Sutton et al. (1993) statistically reanalyzed the data by Harrison et al. (1989) and found some indication for interactions. Similarly, Yamulki et al. (1996) ruled out artefacts on their $\mathrm{NH}_{3}$ flux measurements on the grounds that measured gradients did not significantly deviate from logarithmic profiles. However, even weak changes in concentration profiles that are smaller than the scatter in typical measurement data may lead to a significant heightdependence of $F$ (cf. modelled concentration profiles by Van Oss et al., 1998; Nemitz and Sutton, 2004). 
There is ample evidence that the $\mathrm{NH}_{3}-\mathrm{NH}_{4}^{+}$equilibrium can result in anomalous fluxes: Gallagher et al. (1993, 1997a) observed upward fluxes of particles with a diameter $\left(D_{p}\right)<0.25 \mu \mathrm{m}$ above Dutch heathland and forest ecosystems, which were correlated with times of $\mathrm{NH}_{3}$ emission, while Zhang et al. (1995) attributed apparent $\mathrm{HNO}_{3}$ emission fluxes to dissociation of $\mathrm{NH}_{4} \mathrm{NO}_{3}$. The opposite observation, $\mathrm{HNO}_{3}$ deposition faster than permitted by turbulence, has been reported by Meixner et al. (1990) and can also be seen in data presented by Dollard et al. (1987), also re-analyzed by Sutton et al. (1993). In addition, the potential effect of gtpc on measurements of $\mathrm{NH}_{3}$ exchange fluxes has been estimated by comparison of chemical time-scales, obtained from measurements of the aerosol size distribution, with diffusive time-scales (Kins et al., 1996; Seidl et al., 1996; Nemitz et al., 2000).

Brost et al. (1988) were the first to model the effect of the $\mathrm{NH}_{3}-\mathrm{HNO}_{3}-\mathrm{NH}_{4} \mathrm{NO}_{3}$ equilibrium on surface exchange fluxes of $\mathrm{NH}_{3}$ and successfully reproduced anomalous observations of $\mathrm{HNO}_{3}$ emission and fast $\mathrm{NO}_{3}^{-}$deposition by Huebert et al. (1988) as the effect of $\mathrm{NH}_{4} \mathrm{NO}_{3}$ evaporation. Kramm and Dlugi (1994) proposed an alternative model, which they coupled with an inferential resistance model for the estimation of surface exchange fluxes from single point concentration data. For the application of such models to UK measurement data suggesting upward fluxes of $\mathrm{NH}_{4}^{+}$aerosol, Nemitz et al. (1996) incorporated of the $\mathrm{NH}_{3}-\mathrm{HCl}-\mathrm{NH}_{4} \mathrm{Cl}$ triad as well as of the effect of vertical gradients of $T$ and relative humidity $(h)$ on the values of the dissociation constants. Wyers and Duyzer (1997) observed $\mathrm{NO}_{3}^{-}$aerosol deposition faster than permitted by turbulence above the Dutch forest Speulderbos. Van Oss et al. (1998) successfully simulated this observation and at the same time demonstrated that $\mathrm{NH}_{3}$ emission fluxes obtained at Speulderbos may not originate from the foliage but could at least partly be explained by the evaporation of $\mathrm{NH}_{4} \mathrm{NO}_{3}$ close to or within the canopy. The same explanation was used by Neftel et al. (1997) who reported apparent $\mathrm{HNO}_{3}$ emission gradients. Nemitz et al. (2000) reported emissions of both $\mathrm{NH}_{3}$ and $\mathrm{HCl}$ for an oilseed rape canopy at a coastal Scottish location. Although air concentrations above the canopy were below the equilibrium value, there was potential for $\mathrm{NH}_{4} \mathrm{Cl}$ formation within the canopy. The effect of gpic within forest canopies was modelled by Faust (1996) who also examined its influence on the aerosol size distributions of $\mathrm{NH}_{4}^{+}, \mathrm{NO}_{3}^{-}$and $\mathrm{SO}_{4}^{2-}$ aerosol.

\subsection{The Elspeet experiment}

A field campaign at the Dutch heathland of Elspeet was designed to measure gas and particle fluxes and to study the effects of gas-to-particle conversion and evaporation of the volatile $\mathrm{NH}_{4}^{+}$compounds $\left(\mathrm{NH}_{4} \mathrm{NO}_{3}\right.$ and $\left.\mathrm{NH}_{4} \mathrm{Cl}\right)$. This experiment, conducted between 21 May to 13 June 1996, formed part of the European 'EXAMINE' project ('Ex- change of Ammonia with European Ecosystems') Sutton et al., 1996). This paper reports the flux measurements of particles made in this experiment and examines the whole dataset (including gas fluxes) for indications of gpic. The measurements reported here include size-segregated particle number flux measurements over the range of 0.1 to $0.5 \mu \mathrm{m}$ diameter by eddy-covariance (EC) and fluxes of $\mathrm{NH}_{4}^{+}$derived from continuous automated gradient measurements using the aerodynamic gradient method (AGM). The results of simultaneous gas-phase measurements $\left(\mathrm{NH}_{3}, \mathrm{HNO}_{3}, \mathrm{HCl}, \mathrm{SO}_{2}\right)$ are reported elsewhere (Nemitz et al., 2004), while the effects of gpic were modelled quantitatively by Nemitz and Sutton (2004).

\section{Methods}

\subsection{Aerosol instrumentation}

Particle number fluxes were measured with an EC system comprising of an optical particle counter (ASASP-x, PMS, Boulder, Colorado, US) and an ultrasonic anemometer (Solent Research Anemometer 1012, Gill Instrument, Lymington, UK), a combination similar to that used in previous studies (Sievering, 1983; Katen and Hubbe, 1985; Sievering, 1987; Duan et al., 1988; Gallagher et al., 1993; Gallagher et al., 1997; Nemitz et al., 2002). The ASASP-x was placed at $z=1.3 \mathrm{~m}$, drawing a sample at a rate of $3 \mathrm{ml} \mathrm{s}^{-1}$ through a short narrow bore copper tube from the downwind edge of the ultrasonic anemometer cage at a height of $2.65 \mathrm{~m}$. Tests revealed that this setup had a $95 \%$ response time of $<0.3 \mathrm{~s}$, sufficient for eddy-covariance flux measurements even over short vegetation. The 32 size channels of the ASASP-x, covering the size range 0.1 to $3 \mu \mathrm{m}$, were logged at $10 \mathrm{~Hz}$ on a data acquisition system developed at UMIST and stored on a computer together with the raw turbulence data (Gallagher et al., 1997). In this way a nearly continuous dataset covering 21 days was obtained.

The concentrations of $\mathrm{NH}_{4}^{+}, \mathrm{NO}_{3}^{-}, \mathrm{Cl}^{-}$and $\mathrm{SO}_{4}^{2-}$ were continuously monitored at two heights $(0.64$ and $3.44 \mathrm{~m})$ using a Steam Jet Aerosol Collector (SJAC; ECN, Petten, NL)(Khlystov et al., 1995). Gases were stripped from an air stream of $301 \mathrm{~min}^{-1}$ in a horizontal wet denuder. This denuder consists of two rotating concentric glass cylinders that form a $1.5 \mathrm{~mm}$ annulus. A suitable collection solution ( $\mathrm{NaHSO}_{4}$ for $\mathrm{NH}_{4}^{+}$and $\mathrm{K}_{2} \mathrm{CO}_{3}$ for the anions) is continuously pumped through the denuder using two independent peristaltic pumps: while the solution is pumped out of the denuder at a constant rate, the refilling pump is controlled by an optical measurement to maintain a constant liquid level in the denuder. Within the SJAC after the denuder, the airstream (free of soluble gases) is mixed with steam, allowing hygroscopic aerosol particles to grow to a size large enough to be impacted in a cyclone. At Elspeet two independent twopoint gradient systems were used: in one setup the collection 
Table 1. Summary of the aerosol measurements at Elspeet.

\begin{tabular}{|c|c|c|c|c|}
\hline Flux technique $^{a)}$ & $\begin{array}{l}\text { Parameter (number of } \\
\text { measurement heights) }\end{array}$ & Methodology & $\begin{array}{l}\text { Averaging } \\
\text { time }\end{array}$ & $\begin{array}{l}\text { Manufacturer/ } \\
\text { (method reference) }\end{array}$ \\
\hline & $\begin{array}{l}\text { Aerosol size spectra } \\
\mathrm{NH}_{4}^{+}, \mathrm{Na}^{+}, \mathrm{Mg}_{2}^{+}, \mathrm{K}^{+}, \\
\mathrm{Ca}_{2}^{+}, \mathrm{SO}_{4}^{2-}, \mathrm{NO}_{3}^{-}, \mathrm{Cl}^{-}\end{array}$ & $\begin{array}{l}\text { Berner low pressure } \\
\text { cascade impactor }\end{array}$ & $12 \mathrm{~h}$ & Hauke $\mathrm{GmbH}$, Gmunden, A \\
\hline & $\begin{array}{l}\text { aerosol number size } \\
\text { spectra }(0.01-15 \mathrm{~mm})\end{array}$ & $\begin{array}{l}\text { scanning mobility particle } \\
\text { sizer/aerodynamic } \\
\text { particle sizer }\end{array}$ & $1 \mathrm{~h}$ & $\begin{array}{l}\text { SMPS } 3934 \text { \& APS } 3210 \text {, } \\
\text { TSI GmbH, Aachen, D }\end{array}$ \\
\hline AGM & $\begin{array}{l}\text { aerosol } \mathrm{NH}_{4}^{+}, \mathrm{NO}_{3}^{-}, \\
\mathrm{Cl}^{-}, \mathrm{SO}_{4}^{2-}(2)\end{array}$ & $\begin{array}{l}\text { Steam Jet Aerosol } \\
\text { Collector (SJAC) }\end{array}$ & $\begin{array}{l}30 \text { min cycle } \\
\text { ( } 2 \text { inlets) }\end{array}$ & (Khlystov et al., 1995) \\
\hline AGM & $\begin{array}{l}\mathrm{NH}_{4}^{+}, \mathrm{SO}_{4}^{2-}, \\
\mathrm{NO}_{3}^{-}, \mathrm{Cl}^{-}(\leq 10)\end{array}$ & filter-packs & $1-3 \mathrm{~h}$ & (Harrison and Kitto, 1990) \\
\hline $\mathrm{EC}$ & $\begin{array}{l}\text { aerosol number } \\
\text { fluxes } 0.1-3 \mathrm{~mm} \text { (2) }\end{array}$ & optical particle counter & $20 \mathrm{~min}$ & $\begin{array}{l}\text { ASASP-x, PMS, } \\
\text { Boulder, Colorado, USA }\end{array}$ \\
\hline
\end{tabular}

a) AGM: aerodynamic gradient method; EC: eddy-covariance technique.

solution was analyzed for $\mathrm{NH}_{4}^{+}$in a membrane conductivity cell (Khlystov et al., 1995), while in the second setup the cyclone was connected to an anion-chromatograph (IC), similar to the one described for the gas sampling system of Oms et al. (1996).

These aerosol measurements were complemented by filterpack profile runs of a duration of 1 to $3 \mathrm{~h}$ using up to 10 filter-packs (Harrison and Kitto, 1990) and 12-h runs with a 6-stage Berner impactor (Hauke GmbH, Gmunden, Austria) for the size-resolved sampling of $\mathrm{NH}_{4}^{+}, \mathrm{Na}^{+}, \mathrm{K}^{+}, \mathrm{Mg}^{2+}$, $\mathrm{Ca}^{2+}, \mathrm{NO}_{3}^{-}, \mathrm{Cl}^{-}$and $\mathrm{SO}_{4}^{2-}$. In addition, hourly values of the number particle distribution over the size range from $10 \mathrm{~nm}$ to $15 \mu \mathrm{m}$ were continuously recorded using a combination of a Scanning Mobility Particle Sizer (SMPS 3934) and an Aerodynamic Particle Sizer (APS 3310, both TSI Instruments GmbH, Aachen, Germany). A list of the aerosol measurements carried out at Elspeet is shown in Table 1, while the measurements of gases and micrometeorological parameters have been summarized by Nemitz et al. (2004).

\subsection{Micrometeorological theory}

\subsubsection{The eddy-covariance technique}

Eddy-covariance particle number fluxes $\left(F_{N}\right)$ were calculated from the fluctuations of the particle number concentrations $\left(\chi_{N}\right)$ of the ASASP-x and the vertical wind component $(w)$ from the ultrasonic anemometer sampled at $10 \mathrm{~Hz}$ :

$F_{N}=\overline{w^{\prime} \chi_{N}^{\prime}}=\overline{w \chi_{N}}-\bar{w} \overline{\chi_{N}}$.

Data conditioning included (i) correction for time-lags, (ii) rotational corrections in two dimensions (Tanner and
Thurtell, 1969), (iii) linear detrending and (iv) windowing of the individual time-series. Fontan et al. (1997) presented a spectral analysis model to filter EC data for particle fluxes for low frequencies that may contaminate the flux. Power spectral and co-spectral densities, calculated using a Fast Fourier Transform (FFT) algorithm (Press et al., 1989), showed a considerable contribution of white noise in the high frequency range, which is a sign of poor counting statistics and an intrinsic problem of optical particle counters (OPCs) (Katen and Hubbe, 1985; Duan et al., 1988; Nemitz et al., 2002). Statistical noise is uncorrelated with $w$ and does not affect the flux (Neumann and den Hartog, 1985), but it nevertheless results in high scatter of the (co-)spectral density function. Therefore the spectral analysis model by Fontan et al. (1997) proved to be unsuitable for the ASASP-x data. Nevertheless, the results of Lamaud et al. (1994) and Fontan et al. (1997) were adapted to filter out potential contamination of low frequencies: during two independent studies these authors found that frequencies below $0.01 \mathrm{~Hz}$ did not contribute to turbulent transport, but contaminated the measurements. Consequently, frequencies $<0.01 \mathrm{~Hz}$ were omitted in the calculation of the fluxes.

To fulfil the counting requirements for statistically significant deposition velocities (Fairall, 1984), the 32 size channels had to be allocated to a smaller number of groups that were chosen to match the cut-off diameters of the cascade impactor stages (Table 2). Fluxes proved reliable for $D_{p}<0.50 \mu \mathrm{m}$, but small number concentrations led to poor counting statistics of larger particles. 
Table 2. Grouping of the ASASP-x size classes in comparison with the cut-off diameters of the Berner cascade impactor. Group numbers in brackets represent size ranges, for which fluxes generally had to be discarded due to low number concentrations.

\begin{tabular}{ccccc}
\hline $\begin{array}{c}\text { Impactor } \\
\text { stage no. }\end{array}$ & $\begin{array}{c}\text { Diameter } \\
\left(\mathrm{D}_{p, 50}\right)[\mu \mathrm{m}]\end{array}$ & $\begin{array}{c}\text { ASASP-x } \\
\text { group number }\end{array}$ & $\begin{array}{c}\text { ASASP-x } \\
\text { size channels }\end{array}$ & $\begin{array}{c}\text { ASASP-x diameter } \\
\text { range covered } \\
D_{p}[\mu \mathrm{m}]\end{array}$ \\
\hline 0 & $<0.25$ & 1 & $1-2$ & $0.10-0.12$ \\
(base filter) & & 2 & $3-5$ & $0.13-0.15$ \\
& & 3 & $6-8$ & $0.15-0.18$ \\
1 & $0.25-0.5$ & 5 & $9-11$ & $0.18-0.24$ \\
2 & $0.5-1.0$ & $(6)$ & $12-17$ & $0.24-0.50$ \\
3 & $1.0-2.0$ & $(7)$ & $23-27$ & $0.50-1.0$ \\
4 & $2.0-4.0$ & & & $1.0-2.0$ \\
5 & $4.0-8.0$ & & & \\
\hline
\end{tabular}

\subsubsection{The aerodynamic gradient method}

Above a homogeneous surface the flux $\left(F_{\chi}\right)$ of an inert tracer $(\chi)$ is constant up to a height of roughly $1 / 100 \times$ fetch (the upwind distance to the next surface inhomogeneity). Within this constant-flux layer the flux $\left(F_{\chi}\right)$ of a constituent $(\chi)$ may be derived from the averaged vertical concentration profile $(d \chi / d z)$ (Monteith and Unsworth, 1990):

$F_{\chi}=-K_{H}\left(\frac{z-d}{L}\right) \frac{d_{\chi}}{d_{z}}$,

where $K_{H}$, the eddy-diffusivity for heat and inert tracers, is a function of the height $(z)$ above the zero-plane displacement $(d)$, which was $0.54 \mathrm{~m}$ for the heathland site, and the atmospheric stability, parameterized through the Monin-Obukhov length $(L)$. The application of the aerodynamic gradient method (AGM), which is described in more detail in a companion paper (Nemitz et al., 2004), is particularly useful for chemical species for which fast response sensors are not available.

\subsubsection{Deposition velocities}

The rate at which a tracer is deposited to the surface may be expressed by the height-dependent deposition velocity $\left(V_{d}(z)\right)$, which is the negative ratio of its flux $\left(F_{\chi}\right)$ and the concentration $(\chi)$ at height $z$. $V_{d}(z)$ may also be identified with the reciprocal total resistance for deposition $\left(R_{t}\right)$ :

$V_{d}(z)=-\frac{F_{\chi}}{\chi(z)}=\frac{1}{R_{t}(z)}$.

As discussed in more detail elsewhere (Nemitz et al., 2004), for gases $R_{t}$ is composed of the aerodynamic resistance $\left(R_{a}\right)$, the laminar boundary-layer resistance $\left(R_{b}\right)$ as well as the canopy resistance $\left(R_{c}\right)$, which itself may be composed of a network of parallel and serial resistances. $R_{a}$ describes the turbulent transport between a height $(z)$ and the mean height of momentum exchange, the roughness length $\left(z_{0}\right)$, and for gases $R_{b}$ describes the diffusion through the quasi-laminar sub-layer. For a gas that is perfectly adsorbed by the canopy $\left(R_{c}=0\right)$, the maximum deposition velocity $\left(V_{\max }\right)$ is given by

$V_{\max }=\left(R_{a}+R_{b}\right)^{-1}$.

For particles the interaction with the canopy is complex (Peters and Eiden, 1992), and therefore the effect of the canopy is usually parameterized using the value of $V_{d}$ at $z_{0}\left(V_{d s}=V_{d}\left(z_{0}\right)\right)$ rather than $R_{b}$ and $R_{c}$. This may be calculated from $V_{d}$ and $R_{a}$ as:

$V_{d s}=\left(V_{d}^{-1}-R_{a}(z-d)\right)^{-1}$.

\subsection{Time-scale analysis of gas-particle interactions}

Whether equilibration is sufficiently fast to modify the vertical flux, depends on the Damköhler ratio $\left(D_{r}\right)$ of diffusive time-scale $\left(\tau_{d}\right)$ to chemical time-scale $\left(\tau_{c}\right)$; gpic is often considered important for $D_{r}>0.1$ (Foken et al., 1995). For neutral conditions, $\tau_{d}$ is given by Brost et al. (1988):

$\tau_{d}=\frac{\kappa(z-d)}{1.75 u_{*}}$

where $\kappa$ is the von Kármán constant $(0.41)$ and $u_{*}$ is the friction velocity. For a size-distributed aerosol $\tau_{c}$ may be estimated from measurements of the mass contained in discrete size bins $\left(m_{i}\right)$ as (Wexler and Seinfeld, 1990, 1992):

$\tau_{c}^{-1}=3 \bar{D} \sum_{i} \frac{m_{i}}{\left(1+\frac{\lambda}{\alpha R_{p, i}}\right) R_{p, i}^{2} \rho_{p, i}}$

where $\bar{D}$ is the geometric mean of the diffusivities of the relevant gases (e.g. $\mathrm{NH}_{3}$ and $\mathrm{HNO}_{3}$ ), $\lambda$ is the mean free-path length in air $(0.065 \mu \mathrm{m}), \alpha$ is the accommodation coefficient $(0.01<\alpha<1)$ and $R_{p, i}$ and $\rho_{p, i}$ are radius and density of the particles in size range $i$. A critical value of $u_{*}\left(u_{* \text {,crit }}\right)$ below 
Table 3. Summary of the aerosol concentrations measured at Elspeet.

\begin{tabular}{lcccccccccc}
\hline $\begin{array}{l}\text { chemical species } \\
\text { (instrument) }\end{array}$ & $\begin{array}{c}\mu_{\mathrm{A}} \\
{\left[\mu \mathrm{g} \mathrm{m}^{-3}\right]}\end{array}$ & $\begin{array}{c}\mu_{\mathrm{A}} \\
{\left[\mu \mathrm{eq} \mathrm{m}^{-3}\right]}\end{array}$ & $\begin{array}{c}\sigma_{\mathrm{A}} \\
{\left[\mu \mathrm{g} \mathrm{m}^{-3}\right]}\end{array}$ & $\begin{array}{c}\mu_{\mathrm{M}} \\
{\left[\mu \mathrm{g} \mathrm{m}^{-3}\right]}\end{array}$ & $\begin{array}{c}\sigma_{\mathrm{G}} \\
{\left[\mu \mathrm{g} \mathrm{m}^{-3}\right]}\end{array}$ & $\begin{array}{c}\chi_{\min } \\
{\left[\mu \mathrm{g} \mathrm{m}^{-3}\right]}\end{array}$ & $\begin{array}{c}\chi_{\max } \\
{\left[\mu \mathrm{g} \mathrm{m}^{-3}\right]}\end{array}$ & $\begin{array}{c}\text { coverage } \\
{[\text { days }]}\end{array}$ & $\begin{array}{c}\text { meas } t \\
{[\mathrm{~min}]}\end{array}$ & $\begin{array}{c}N \\
{[\#]}\end{array}$ \\
\hline $\mathrm{NH}_{4}^{+}-\mathrm{N}$ (SJAC) & 3.08 & 0.22 & 2.83 & 2.22 & 2.58 & 0.00 & 14.73 & 22 & 30 & 700 \\
$\mathrm{SO}_{4}^{2-}-\mathrm{S}$ (SJAC) & 1.55 & 0.097 & 1.42 & 1.11 & 0.75 & 0.21 & 9.63 & 22 & 30 & 227 \\
$\mathrm{NO}_{3}^{-}$-N (SJAC) & 1.15 & 0.082 & 1.31 & 0.72 & 0.62 & 0.04 & 8.36 & 22 & 30 & 158 \\
$\mathrm{Cl}^{-}$ & 0.54 & 0.015 & 0.42 & 0.39 & 2.09 & 0.10 & 2.10 & 22 & 30 & 701 \\
\hline
\end{tabular}

$\overline{\mu_{\mathrm{A}}}$ : arithmetic mean; $\sigma_{\mathrm{A}}$ : arithmetic standard deviation; $\mu_{\mathrm{M}}:$ median; $\sigma_{\mathrm{G}}:$ geometric standard deviation; $\chi_{\min }, \chi_{\max }:$ minimum and maximum concentration; meas. $t$ : measurement time; $N$ : number of observations.
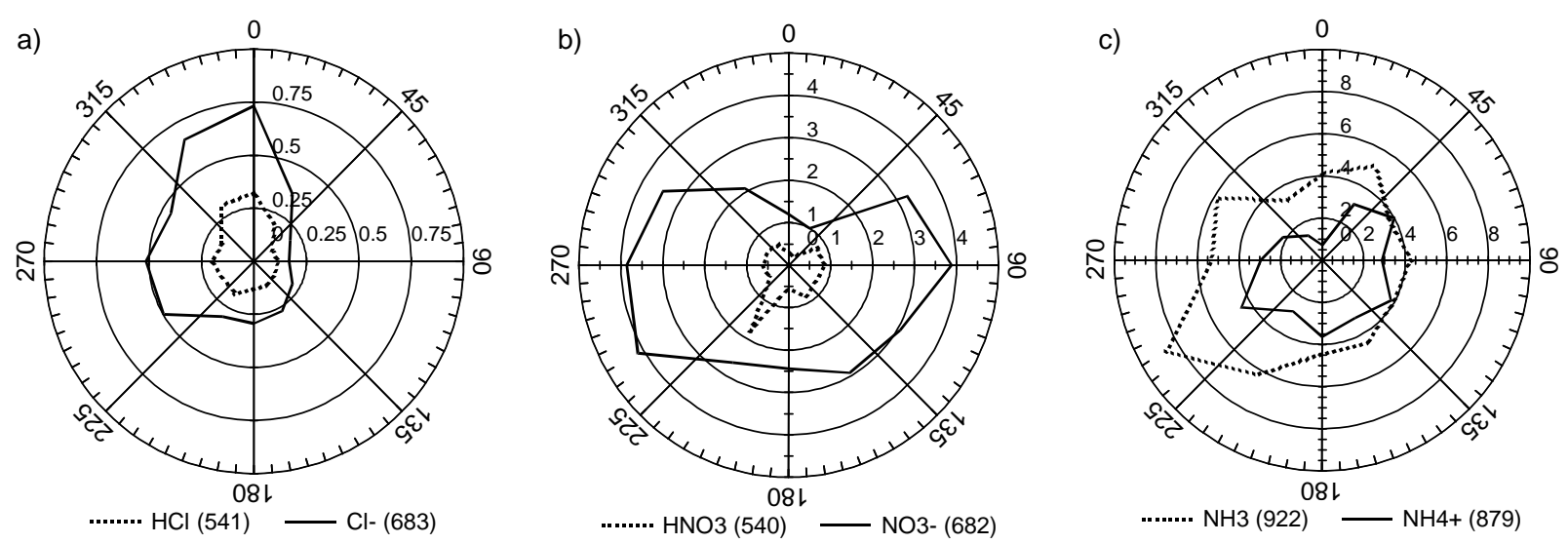

Fig. 1. Wind-sector dependencies of median concentration $\left(\mu \mathrm{g} \mathrm{m}^{-3}\right.$ as $\mathrm{Cl}$ and $\left.\mathrm{N}\right)$ of (a) $\mathrm{HCl}_{\text {and }} \mathrm{Cl}^{-}$aerosol, (b) $\mathrm{HNO}_{3}$ and $\mathrm{NO}_{3}^{-}$aerosol, as well as (c) $\mathrm{NH}_{3}$ and $\mathrm{NH}_{4}^{+}$measured at Elspeet, with the number of observation provided in parentheses.

which gpic may be expected to affect gradients can be calculated by solving the inequality $\tau_{d}>0.1 \times \tau_{c}$ for $u_{*}$ (Nemitz et al., 2000).

\section{Results}

3.1 Comparison of associated gas and aerosol concentrations

Statistics of the aerosol concentrations are summarized in Table 3. On an equivalent basis, $\mathrm{NH}_{4}^{+}$was on average balanced by the sum of $\mathrm{SO}_{4}^{2-}, \mathrm{NO}_{3}^{-}$and $\mathrm{Cl}^{-}$, indicating that (a) other cations such as $\mathrm{Na}^{+}$were of secondary importance, (b) that the $\mathrm{SO}_{4}^{2-}$ was fully neutralized and (c) that $\mathrm{NH}_{4} \mathrm{NO}_{3}$ is ubiquitous in the Netherlands: on average, $\mathrm{NH}_{4}^{+}$was evenly distributed between $\mathrm{SO}_{4}^{2-}$ and $\mathrm{NO}_{3}^{-}$.

The wind sector dependency of the concentration of selected associated gas and aerosol species, calculated for $30^{\circ}$ wind sectors, is presented in Fig. 1. Each wind sector distribution represents between 500 and 1000 half-hourly data points. The various chemical species show distinct wind sector dependencies reflecting differences in their origin. A high similarity was found for the wind sector dependency of $\mathrm{HCl}$ and $\mathrm{Cl}^{-}$concentrations (Fig. 1a). Both concentrations were very low, showing elevated concentrations in the more maritime wind sectors $\mathrm{W}$ to $\mathrm{N}$. The concentration of $\mathrm{HNO}_{3}$ gas was much lower than of $\mathrm{NO}_{3}^{-}$aerosol (Fig. 1b) and despite an otherwise high similarity, $\mathrm{HNO}_{3}$ showed a peak in SSW, which also coincided with the maximum in the $\mathrm{SO}_{2}$ concentration (not shown), while the distribution of $\mathrm{SO}_{4}^{2-}$ was similar to that of $\mathrm{NO}_{3}^{-} \cdot \mathrm{NH}_{4}^{+}$and $\mathrm{NH}_{3}$ also showed very similar wind dependencies (Fig. 1c), but an elevated $\mathrm{NH}_{3}$ concentration at WNW was not reflected in the $\mathrm{NH}_{4}^{+}$.

\subsection{Eddy-covariance particle number flux measurements}

Despite the poor counting statistics reflected in noisy powerspectra the diurnal cycles of the surface values of the particle deposition velocities $\left(V_{d s}\right)$ of the five smallest size-classes (Table 2) show a clear structure. Two distinct patterns can be observed, which are exemplified in Fig. 2: on some days all size classes showed deposition throughout the day, and an increase of $V_{d s}$ with particle size (Fig. 2a), which is in agreement with other measurements and model predictions for this size range $\left(D_{p}>0.1 \mu \mathrm{m}\right)$ (Gallagher et al., 1997). Many days, however, included periods, during which smaller particles $\left(D_{p}<0.18 \mu \mathrm{m}\right)$ showed some emission, while larger particles were continuously deposited. This emission was usually restricted to the afternoon ( 13:00-18:00 GMT; see Fig. 6d), 

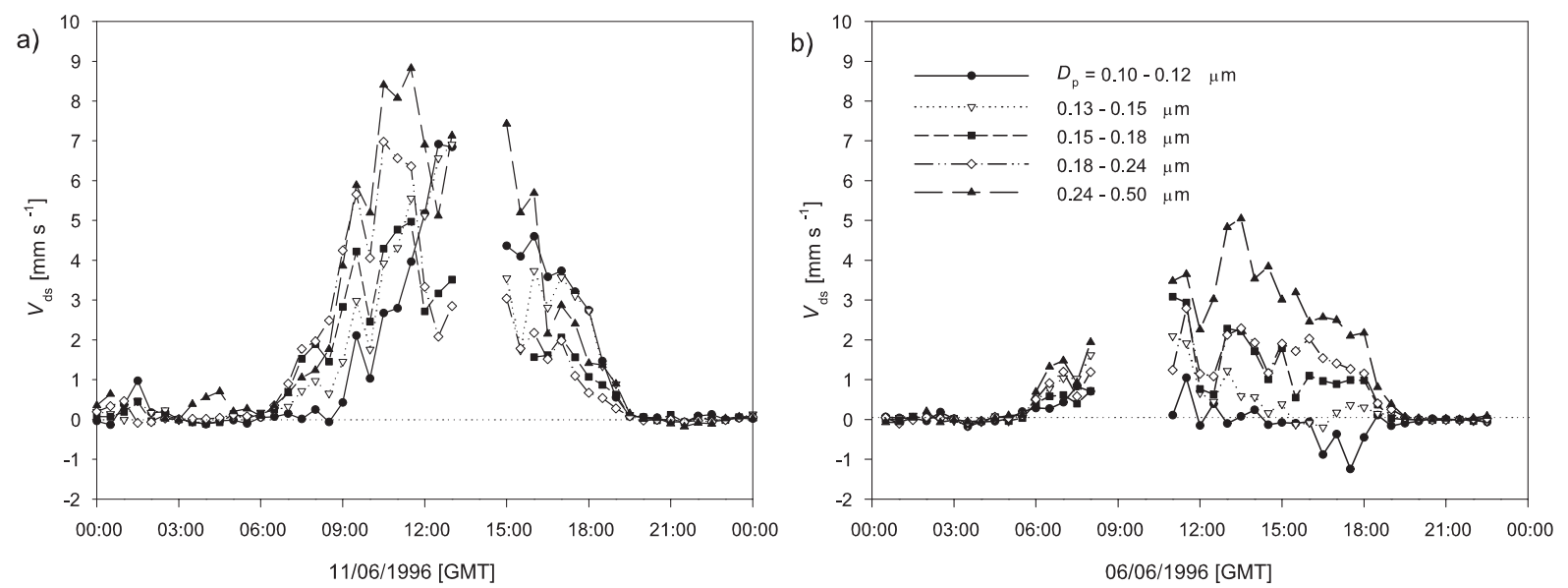

Fig. 2. Example daily courses of the deposition velocity of five size classes of particles as measured by eddy-covariance with the ASASP-x. In case (a) particles of all sizes are continuously deposited, at a rate that increases with particle size, whereas (b) on 6 June apparent emission of small particles was observed in the afternoon.

but occasionally it occurred for most of the day (Fig. 2b; see also Figs. 6d and 7d).

Typical values of $V_{d s}$ at Elspeet ranged from 1 to $9 \mathrm{~mm} \mathrm{~s}^{-1}$ during the day and $<0.5 \mathrm{~mm} \mathrm{~s}^{-1}$ at night. Parameterizations of $V_{d s}$ are commonly normalized by $u_{*}$, and Fig. 3 shows the averaged plots of measured $V_{d s} / u_{*}$ as a function of the stability parameter $\left(L^{-1}\right)$. The data included in this figure were filtered for sufficient fetch $(>200 \mathrm{~m})$, but not for statistical validity as described by Fairall (1984). Since counting requirements increase with decreasing $V_{d s}$, this filtering procedure tended to eliminate the small values of $V_{d s}$ and biased the night-time average $V_{d s}$ towards unrealistically large values. Since each data point in Fig. 3 already represents an average of at least twenty 20 -min values, statistical variation due to poor counting statistics is largely eliminated. Following similarity theory considerations, Wesley et al. (1985) suggested a generic response curve of $V_{d s} / u_{*}$ as a function of stability, the parameter of which were here chosen to provide a good fit to the measured values for $L^{-1}>-0.07 \mathrm{~m}^{-1}$ (Fig. 3):

$\frac{V_{d s}}{u_{*}}= \begin{cases}a_{1}\left(1+\left(-a_{2} L^{-1}\right)^{\frac{2}{3}}\right), & L \leq 0 \\ a_{1} & , L>0\end{cases}$

with $a_{1}=0.001 ; a_{2}[\mathrm{~m}]=960 D_{p}[\mu \mathrm{m}]-88$

For highly unstable conditions $\left(L^{-1}<-0.07 \mathrm{~m}^{-1}\right)$, the measured curves of the three smallest size classes fall increasingly below the predicted lines, indicating frequent occurrence of apparent emission fluxes. For comparison, Wesley et al. (1985) derived parameters of $a_{1}=0.002$ and $a_{2}=300$.

\subsection{Deposition velocities of $\mathrm{NH}_{4}^{+}$}

Values of $\chi_{\mathrm{NH}_{4}^{+}}(1 \mathrm{~m})$ and $V_{d}(1 \mathrm{~m})$ as derived from the gradients measured with the SJAC and filter-packs are presented

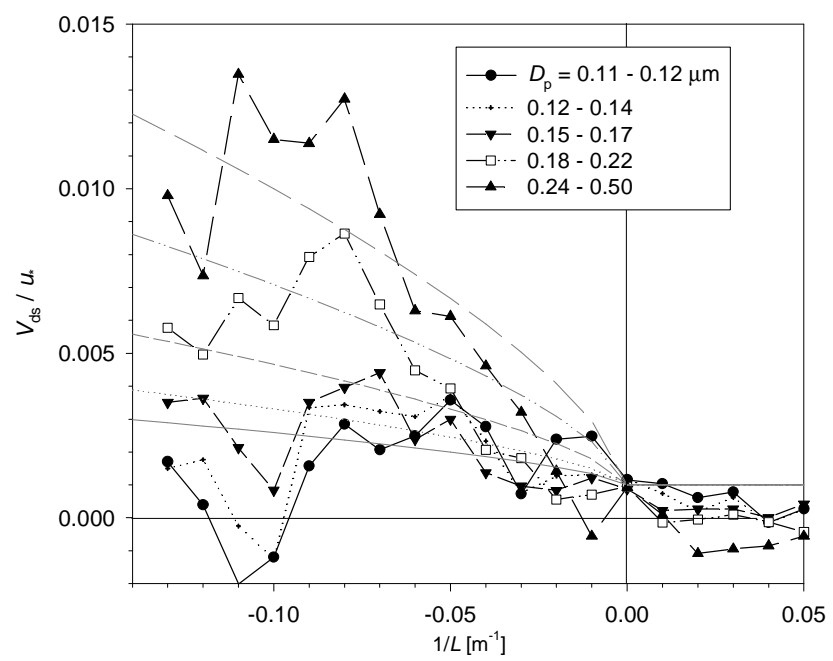

Fig. 3. Normalized values of the measured deposition velocity $\left(V_{d s} / u_{*}\right)$ as a function of the stability parameter $\left(L^{-1}\right)$ for five ranges of particle diameter $\left(D_{p}\right)$. Theoretically predicted curves according to Eq. (12) are also shown (grey lines).

in Fig. 4. The SJAC detected somewhat higher concentrations than the filter-packs. This might be explained by the possibility for evaporation of collected $\mathrm{NH}_{4}^{+}$in the filterpacks. However, the filter pack $\mathrm{NH}_{4}^{+}$shows better agreement with the sum of SJAC $\mathrm{SO}_{4}^{2-}, \mathrm{NO}_{3}^{-}$and $\mathrm{Cl}^{-}$than the SJAC $\mathrm{NH}_{4}^{+}$, suggesting that the SJAC overestimates $\mathrm{NH}_{4}^{+}$at times. This overestimate would be reflected in slightly overestimated fluxes, but it does not affect values of $V_{d}$.

The 30-min values of $V_{d}$ derived from the SJAC gradients show considerable scatter, but the 3 -h running mean reveals a consistent pattern with very small $V_{d}$ during the night and values of $10 \mathrm{~mm} \mathrm{~s}^{-1}$ or above during the day. Bearing in mind that $\mathrm{NH}_{4}^{+}$evaporation from low-pressure 


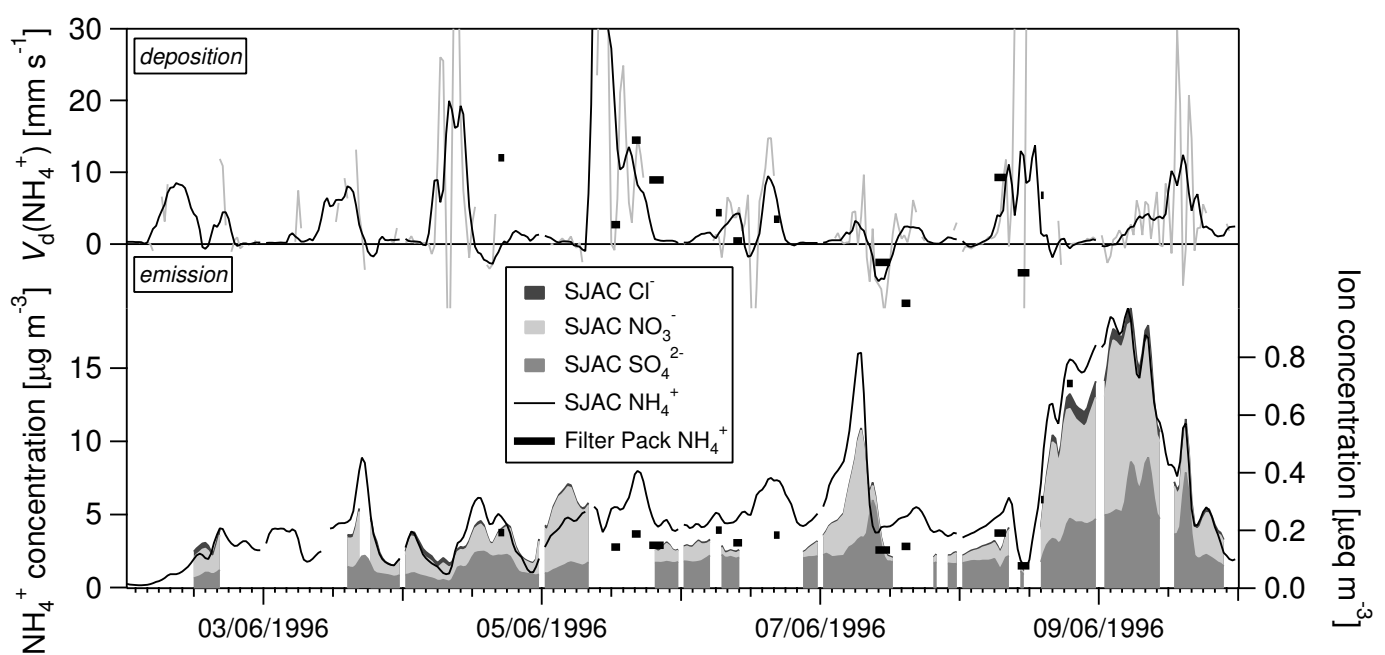

Fig. 4. Example time series of $\mathrm{NH}_{4}^{+}$concentrations and deposition velocities $\left(V_{d}\right)$ derived by gradient method from the SJAC and filter-pack data. For the SJAC both 30-min measurement data (thin grey) and a 3-h running mean (bold black) are shown. Also shown are the equivalent concentrations of the main anions associated with $\mathrm{NH}_{4}^{+}\left(\mathrm{SO}_{4}^{2-}, \mathrm{NO}_{3}^{-}\right.$and $\left.\mathrm{Cl}^{-}\right)$.

Table 4. Chemical time-scales $\left(\tau_{c}\right)$ calculated for the Berner impactor runs from the mass distribution of the total hydrophilic aerosol. Also shown are critical values of $u_{*}$, below which the effect of gpic on flux measurements is expected to become important.

\begin{tabular}{|c|c|c|c|c|c|c|}
\hline \multirow[b]{2}{*}{$\begin{array}{c}\text { Run } \\
\text { no. }\end{array}$} & \multirow[b]{2}{*}{$\begin{array}{l}\text { Start date/time } \\
\text { [GMT] }\end{array}$} & \multirow[b]{2}{*}{$\begin{array}{l}\text { Duration } \\
\quad[\mathrm{h}]\end{array}$} & \multicolumn{2}{|c|}{$\alpha=0.1$} & \multicolumn{2}{|c|}{$\alpha=1$} \\
\hline & & & $\begin{array}{c}\tau_{c} \\
{[\mathrm{~min}]}\end{array}$ & $\begin{array}{c}u_{* \text { crit. }} \\
{\left[\mathrm{m} \mathrm{s}^{-1}\right]}\end{array}$ & $\begin{array}{c}\tau_{c} \\
{[\mathrm{~min}]}\end{array}$ & $\begin{array}{l}u_{* \text { crit. }} \\
{\left[\mathrm{m} \mathrm{s}^{-1}\right]}\end{array}$ \\
\hline 1 & $21.05 .9608: 00$ & $12: 00$ & 3.95 & 0.025 & 0.75 & 0.130 \\
\hline 2 & 21.05.96 20:00 & 12:00 & 3.97 & 0.025 & 0.84 & 0.117 \\
\hline 9 & $29.05 .9608: 00$ & $12: 00$ & 4.87 & 0.020 & 0.99 & 0.099 \\
\hline 10 & 29.05.96 20:00 & $12: 00$ & 14.40 & 0.007 & 3.19 & 0.031 \\
\hline 11 & $30.05 .9608: 05$ & 12:00 & 5.56 & 0.018 & 1.12 & 0.087 \\
\hline 12 & $31.05 .9608: 00$ & $12: 00$ & 8.19 & 0.012 & 1.67 & 0.058 \\
\hline 13 & 01.06.96 08:00 & $12: 00$ & 8.66 & 0.011 & 1.75 & 0.056 \\
\hline 14 & 04.06.96 08:00 & $12: 00$ & 4.71 & 0.021 & 0.92 & 0.106 \\
\hline 15 & 04.06.96 20:00 & $12: 00$ & 4.81 & 0.020 & 1.05 & 0.093 \\
\hline 16 & 05.06.96 11:00 & 09:00 & 6.30 & 0.015 & 1.23 & 0.080 \\
\hline 17 & 05.06.96 20:00 & $12: 00$ & 5.74 & 0.017 & 1.10 & 0.089 \\
\hline 18 & 06.06.96 08:00 & $12: 00$ & 9.28 & 0.011 & 1.75 & 0.056 \\
\hline 19 & 06.06.96 20:00 & 12:00 & 3.08 & 0.032 & 0.60 & 0.163 \\
\hline 20 & 07.06.96 08:00 & 12:00 & 11.40 & 0.009 & 2.23 & 0.044 \\
\hline 21 & 07.06.96 20:00 & 12:00 & 6.16 & 0.016 & 1.27 & 0.077 \\
\hline 22 & $10.06 .9620: 00$ & 12:00 & 3.94 & 0.025 & 0.80 & 0.122 \\
\hline 23 & 11.06.96 08:00 & $12: 00$ & 3.22 & 0.030 & 0.64 & 0.153 \\
\hline
\end{tabular}

impactors can be considerable, the impactor measurements indicated that the bulk of the $\mathrm{NH}_{4}^{+}$was contained in particles of $D_{p}<0.5 \mu \mathrm{m}$, with an average mass median diameter (MMD) of about $0.29 \mu \mathrm{m}$. The $V_{d}$ of $\mathrm{NH}_{4}^{+}$should therefore be comparable to those derived from the EC measurements above. By contrast, on several days considerably larger $V_{d}$ values were derived from the AGM than from the EC measurements.

\subsection{Potential for chemical interactions}

\subsubsection{State of gas/aerosol phase equilibrium}

By comparing the measured gas concentration products $\left(K_{m}\right)$ $\mathrm{NH}_{3} \times \mathrm{HNO}_{3}$ and $\mathrm{NH}_{3} \times \mathrm{HCl}$ with the theoretical concentration products in equilibrium with the particle phase $\left(K_{e}\right)$, it may investigated whether air masses are in equilibrium, or whether there is potential for gtpc or potential for aerosol evaporation. At Elspeet, measurements of vertical concentration gradients of $\mathrm{NH}_{3}, \mathrm{HNO}_{3}$ and $\mathrm{HCl}$ reported by $\mathrm{Ne}$ mitz et al. (2004) enabled comparisons of $K_{m}$ and $K_{e}$ to be carried out at several heights, as discussed in detail by Nemitz (1998). These show that at the average measurement height of $1 \mathrm{~m}$ above the canopy, there was potential for aerosol evaporation for most of the time, except for some periods with $h>85 \%$. However, for $\mathrm{NH}_{4} \mathrm{NO}_{3}$, concentration products extrapolated to a notional height of $50 \mathrm{~m}$ above the heathland vegetation were close to their equilibrium value. In addition, the deposition gradient of both $\mathrm{NH}_{3}$ and $\mathrm{HNO}_{3}$ together with an increase in temperature resulted in $K_{m} \ll K_{e}$ close to the surface, and therefore in strong potential for aerosol evaporation. For $\mathrm{NH}_{4} \mathrm{Cl}$, it was found that $K_{m}<K_{e}$ at all heights. Nemitz (1998) concluded that although both $\mathrm{NH}_{4}^{+}$and $\mathrm{Cl}^{-}$were present, these were externally mixed, i.e. contained in different particles, and could therefore not evaporate jointly.

\subsubsection{Chemical time-scales}

To assess whether chemical conversion above the canopy would have been fast enough to affect gradient measurements of the $\mathrm{NH}_{3}$ flux, chemical time-scales were estimated from the particle size spectra measured with both Berner impactor 


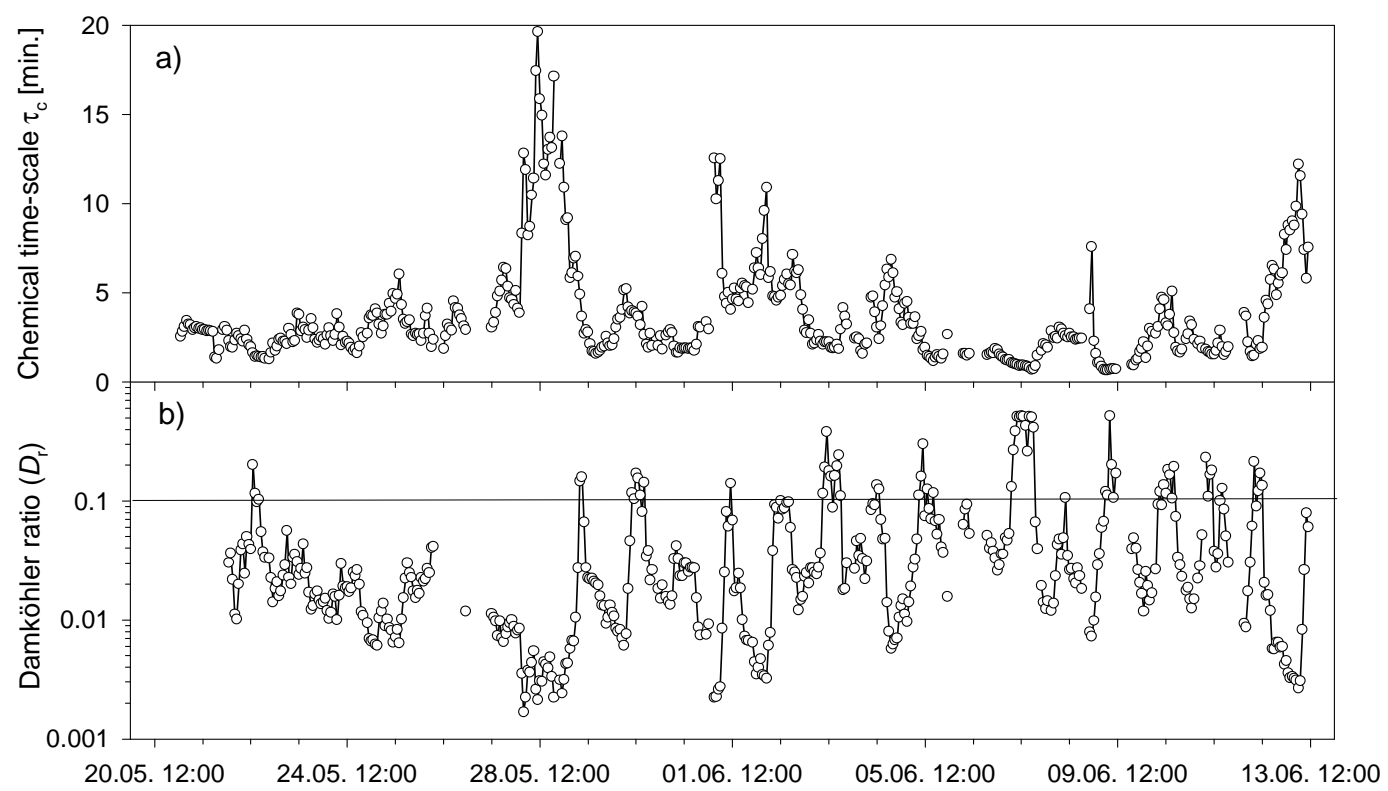

Fig. 5. (a) Chemical time-scales $\left(\tau_{c}\right)$ estimated from the SMPS/APS particle number size distribution, assuming the reaction to take part at the surface of half of the particles and $\alpha=1$. (b) Damköhler ratio $\left(D_{r}\right)$ for a height of $z-d=3 \mathrm{~m}$. Chemical conversions may become important for $D_{r}>0.1$ (e.g. Foken et al., 1995).

and the particle sizers (SMPS, APS) according to Eq. (11). Table 4 shows the values calculated for $z-d=3 \mathrm{~m}$ from the total aerosol mass detected by the impactor for two plausible values of the sticking coefficient $(\alpha)$.

For $\alpha=1$ the critical value of $u_{*}$, below which the effect of gpic on surface exchange fluxes becomes significant $\left(u_{* \text { crit }}\right)$, often approached or exceeded $0.1 \mathrm{~m} \mathrm{~s}^{-1}$, and chemical conversions may therefore have been important. Figure 5 shows the Damköhler ratio $\left(D_{r}\right)$ of turbulent transport time-scale to chemical time-scale for $z-d=3 \mathrm{~m}$, calculated from the size distribution of the total particle number as measured with the SMPS and APS systems, assuming that $50 \%$ of the particles contained $\mathrm{NH}_{4} \mathrm{NO}_{3}$. This arbitrary particle fraction was assumed to contain $\mathrm{NH}_{4}^{+}$and to be available for the heterogeneous reaction (Wexler and Seinfeld, 1990). During the first part of the campaign $D_{r}$ was small, due to high wind speeds and low aerosol loadings. Values of $D_{r}$ larger than a critical value of 0.1 were observed during daytime later on in the campaign, and here this time-scale analysis predicts that chemical conversions may have altered the flux.

3.4.3 Temporal correlation between surface exchange fluxes of $\mathrm{NH}_{3}$, acids and aerosols

The surface/atmosphere exchange of the individual chemical species depends on too many factors (meteorological conditions, air mass, plant physiological parameters, aerosol compositions) for interactions between the phase (disequilibrium and surface fluxes to show up in statistical bulk analyses. Indication for chemical interactions may nevertheless be seen in the temporal correlation of several unexpected measurement features on individual days. This section draws together results of the gas flux measurements (Nemitz et al., 2004), the comparison of measured vapour phase concentration products with their theoretical equilibrium values $(\mathrm{Ne}-$ mitz, 1998) and the here presented aerosol flux measurements.

In Fig. 6 the diurnal cycles of the $\mathrm{NH}_{3}$ flux and $V_{d}$ of $\mathrm{HNO}_{3}, \mathrm{HCl}$ and $\mathrm{NH}_{4}^{+}$as derived by the aerodynamic gradient method (AGM) are shown together with the sizeresolved particle $V_{d s}$ by EC. Between 07:00 and 08:00 GMT two changes occur: i) the $\mathrm{NH}_{3}$ flux estimated with AGM switched from deposition to emission and ii) $V_{d}$ of $\mathrm{HCl}$ and $\mathrm{HNO}_{3}$ deviated increasingly from $V_{\max }$ (Fig. 6b).

An alternative estimate of $V_{d s}\left(\mathrm{NH}_{4}^{+}\right)$may be obtained by combining the long-term average of the $\mathrm{NH}_{4}^{+}$size distribution derived from the cascade impactor with the sizedependent particle deposition velocity derived by EC (e.g. Gallagher et al., 1993). In the afternoon $V_{d s}\left(\mathrm{NH}_{4}^{+}\right)$derived by AGM from the SJAC gradient showed positive divergence from this value (Fig. 6b), and at the same time the EC $V_{d s}$ of small particles $\left(D_{p}<0.18 \mu \mathrm{m}\right)$ was reduced, while emission of the two smallest size classes was found after 14:00 GMT.

Figure 7 shows a second example of the correlation between periods of a high $R_{c}\left(\mathrm{NH}_{3}\right)$ or $\mathrm{NH}_{3}$ emission derived by the gradient technique, fast $\mathrm{NH}_{4}^{+}$deposition by $\mathrm{AGM}$ and apparent particle emission of small particles by EC. Whereas $\mathrm{NH}_{3}$ was found to deposit at $V_{\max }$ during night within the accuracy of the measurements (Fig. 7b), $V_{d}$ was much smaller than $V_{\max }$ during daytime, and the measurements indicate 


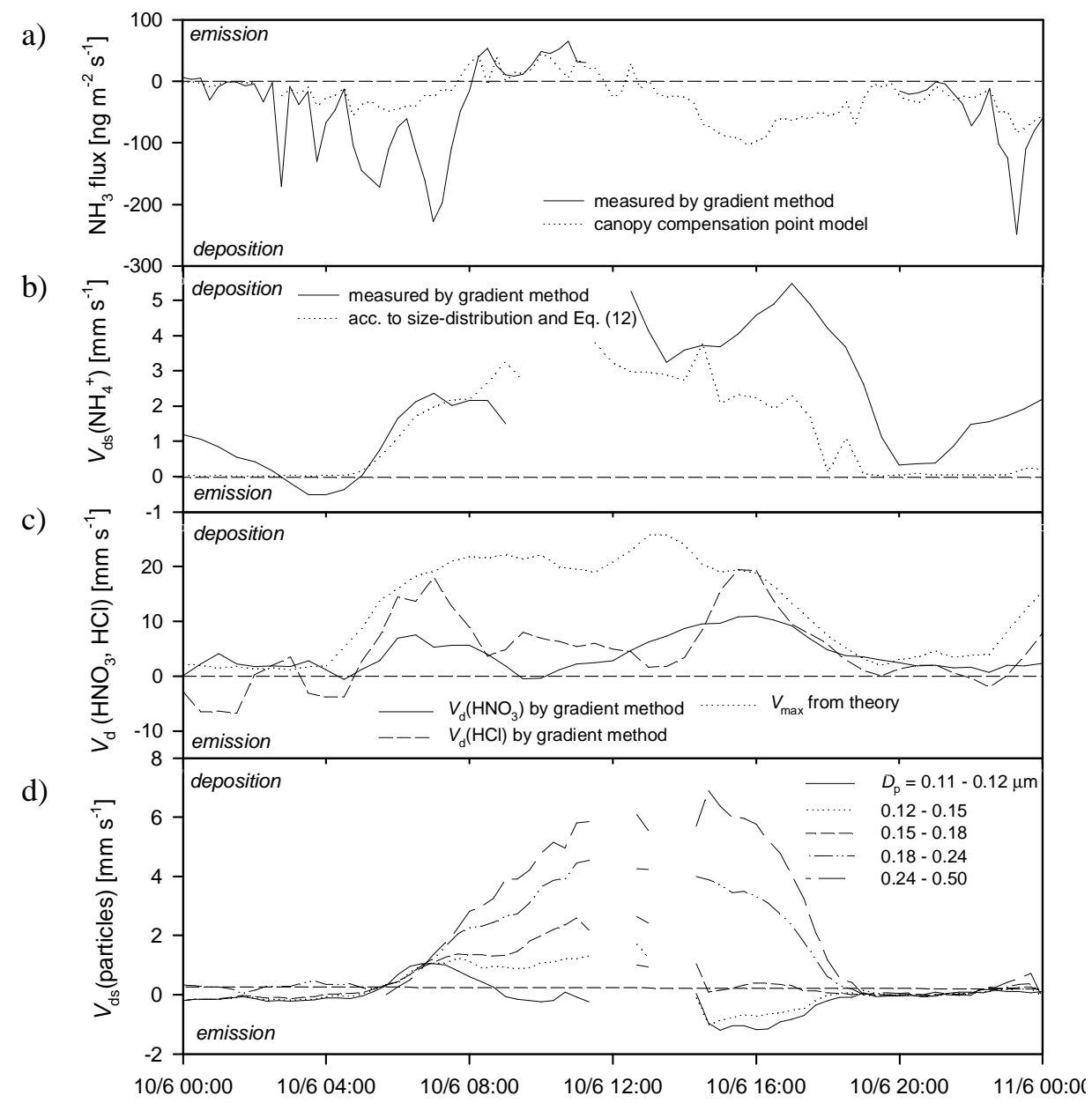

Fig. 6. Time series obtained at Elspeet on 10 June 1996. (a) $\mathrm{NH}_{3}$ fluxes as measured and predicted by the canopy compensation point model (Nemitz et al., 2004). (b) $\mathrm{HNO}_{3}$ and $\mathrm{HCl}$ deposition velocity $\left(V_{d}\right)$ in comparison with their maximum value $\left(V_{\max }\right)$. (c) $V_{d s}\left(\mathrm{NH}_{4}^{+}\right)$ in comparison with the value according to the $\mathrm{NH}_{4}^{+}$size-distribution and parameterization of Eq. (12), all derived by gradient method. (d) Size-dependent particle $V_{d s}$ as obtained by EC with the ASASP-x.

$\mathrm{NH}_{3}$ emission from 08:00-13:00 GMT (Fig. 7a). During the same period, high $\mathrm{NH}_{4}^{+} V_{d s}$ by AGM (Fig. 7c) and substantial emission of particles up to a size of $0.18 \mu \mathrm{m}$ by EC were observed (Fig. 7d).

On first sight the high values of $V_{d s}\left(\mathrm{NH}_{4}^{+}\right)$by AGM seem to be in contradiction to the observation of reduced $V_{d s}$ and even emission of small particles by EC. Each of these observations can be used to infer a first-order correction for the $\mathrm{NH}_{3}$ flux:

1. From the combination of the $\mathrm{SJAC} \mathrm{NH}_{4}^{+}$concentrations, the average size-distribution from the impactor and $V_{d s}\left(D_{p}\right)$ according to Eq. (12), an "expected" $\mathrm{NH}_{4}^{+}$ surface exchange flux and $V_{d s}\left(\mathrm{NH}_{4}^{+}\right)$can be derived (Figs. 6b and 7c). This may be compared with the measured $\mathrm{NH}_{4}^{+}$flux to estimate the amount of $\mathrm{NH}_{4}^{+}$, which would have had to evaporate and contribute to the $\mathrm{NH}_{3}$ flux at the measurement height. Application of this cor- rection predicts larger $\mathrm{NH}_{3}$ deposition (or reduced $\mathrm{NH}_{3}$ emission) at the surface that at the measurement height.

2. A second correction may be estimated from comparison of measured size-dependent particle number $V_{d s}$ by EC and Eq. (12). From the particle volume and the density of $\mathrm{NH}_{4} \mathrm{NO}_{3}$, the difference in the number fluxes may be related to a difference in the $\mathrm{NH}_{4}^{+}$flux, which can subsequently be converted into the additional $\mathrm{NH}_{3}$ emission, necessary to evoke the slow particle deposition or emission observed by EC. This correction leads to increased $\mathrm{NH}_{3}$ emission (or reduced $\mathrm{NH}_{3}$ deposition) at the surface compared with the measurements.

Naturally, these two "corrections" have opposite effects on the $\mathrm{NH}_{3}$ flux as exemplified in Fig. 7a. However, sizedependent modelling of the effect of gpic on EC measurements of aerosol fluxes (Nemitz and Sutton, 2004) revealed that, contrary to intuition, apparent emission of small 


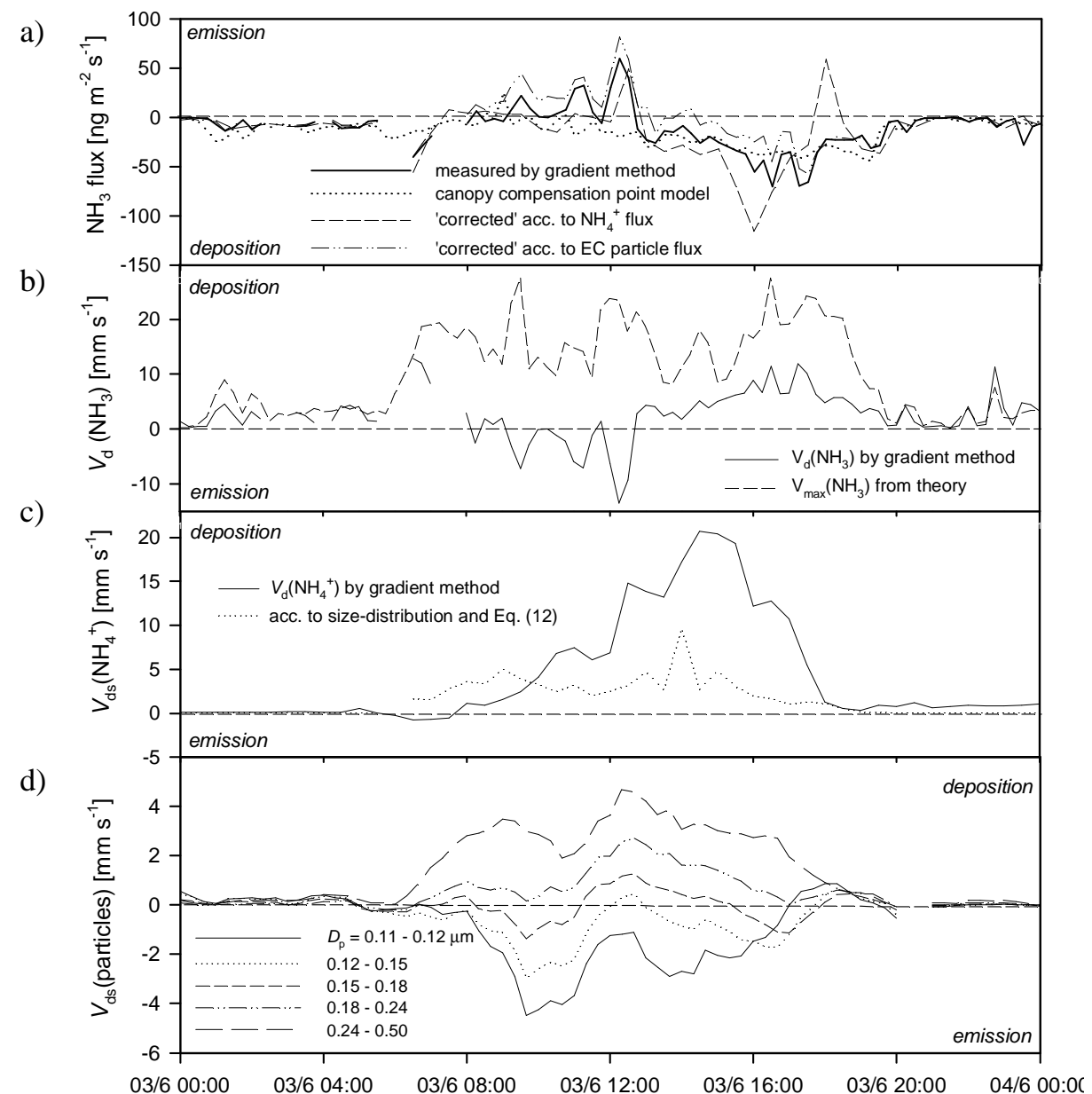

Fig. 7. Time series obtained at Elspeet on 3 June 1996. (a) $\mathrm{NH}_{3}$ flux as measured and modelled by the canopy compensation point model (Nemitz et al., 2004). (b) $\mathrm{NH}_{3}$ deposition velocity $\left(V_{d}\right)$ compared with $V_{\max }$. (c) $V_{d s}\left(\mathrm{NH}_{4}^{+}\right)$obtained with the SJAC, all by gradient method. d) Particle deposition velocities as obtained by EC with the ASASP-x. Also shown in (a) are the fluxes of $\mathrm{NH}_{3}$ which would be necessary to produce i) the fast apparent $\mathrm{NH}_{4}^{+}$deposition (dashed line) and ii) the observed particle number emission of small particles (dashed-dotted line).

particles of certain sizes may also result from aerosol evaporation. Particles that evaporate during deposition contribute to a larger number concentration of particles of a smaller size class close to the surface, leading to apparent emission gradients in this smaller size class. This reconciles the anomalous EC measurements and the over-fast $\mathrm{NH}_{4}^{+}$deposition. Thus the first "correction" is likely to be more appropriate, and at daytime the uncorrected gradient measurements overestimate the $\mathrm{NH}_{3}$ emission flux (or under-estimated the deposition flux) by about $20 \mathrm{ng} \mathrm{m}^{-2} \mathrm{~s}^{-1}$ (or on average $28 \%$ ). This is also supported by the fact that for this day a canopy compensation point resistance model predicts smaller emission (larger deposition) than indicated by the uncorrected gradient measurements (Fig. 7a)(Nemitz et al., 2004).

\section{Discussion}

\subsection{Gas-aerosol conversions during advection}

At Elspeetsche Veld the wind sector dependency of the median $\mathrm{HCl}$ concentration followed that of $\mathrm{Cl}^{-}$aerosol very closely (Fig. 1a), and the impactor measurements showed that at maritime wind directions, the coarse mode $\mathrm{NO}_{3}^{-}$can be as large as the $\mathrm{Cl}^{-}$equivalent concentration (not shown). Both observations indicate that, by the time the maritime air reached the site, a considerable fraction of the sea salt chloride had been substituted by $\mathrm{NO}_{3}^{-}$, and that this process presented the main $\mathrm{HCl}$ source at this site. The correlations between $\mathrm{HNO}_{3}$ and $\mathrm{NO}_{3}^{-}$as well as $\mathrm{NH}_{3}$ and $\mathrm{NH}_{4}^{+}$emphasize the role of $\mathrm{HNO}_{3}$ and $\mathrm{NH}_{3}$ as precursor gases of $\mathrm{NH}_{4} \mathrm{NO}_{3}$ aerosol (Fig. $1 \mathrm{~b}$ and c). Whereas both $\mathrm{NH}_{3}$ and $\mathrm{NH}_{4}^{+}$show the highest concentrations in the SW, where several farms are located at a distance of at least $5 \mathrm{~km}$, the closest farm 
Table 5. Summary of average aerosol dry deposition fluxes to the heathland at Elspeet during the 3-week measurement period in comparison with gaseous ammonia and nitric acid (Nemitz et al., 2004). Values in parenthesis are\% of the total measured dry $\mathrm{N}_{\text {input }}\left(\mathrm{sum}\right.$ of $\mathrm{NH}_{3}+$ $\mathrm{HNO}_{3}+\mathrm{NH}_{4}^{+}+\mathrm{NO}_{3}^{-}$). Daytime is defined according to non-zero solar radiation as 05:00 to 20:00 GMT.

\begin{tabular}{l|cc|cc|cc}
\hline & \multicolumn{2}{|c|}{ Average } & \multicolumn{2}{|c|}{ Daytime } & \multicolumn{2}{c}{ Nighttime } \\
Species & $\mathrm{ng} \mathrm{m}^{-2} \mathrm{~s}^{-1}$ & $\mathrm{~kg} \mathrm{ha}^{-1} \mathrm{yr}^{-1}$ & $\mathrm{Ng} \mathrm{m}^{-2} \mathrm{~s}^{-1}$ & $\mathrm{~kg} \mathrm{ha}^{-1} \mathrm{yr}^{-1}$ & $\mathrm{ng} \mathrm{m}^{-2} \mathrm{~s}^{-1}$ & $\mathrm{~kg} \mathrm{ha}^{-1} \mathrm{yr}^{-1}$ \\
\hline $\mathrm{NH}_{3}-\mathrm{N}$ & $43(75)$ & 14 & $41(66)$ & 13 & $45(90)$ & 14 \\
$\mathrm{HNO}_{3}-\mathrm{N}$ & $3.2(6)$ & 1.0 & $5.5(9)$ & 1.7 & $0.77(2)$ & 0.24 \\
$\mathrm{NH}_{4}^{+}-\mathrm{N}$ & $8.6(15)$ & 2.7 & $12(19)$ & 3.9 & $3.1(6)$ & 0.97 \\
$\mathrm{NO}_{3}^{-}-\mathrm{N}$ & $2.3(4)$ & 0.74 & $3.9(6)$ & 1.2 & $0.91(2)$ & 0.29 \\
$\mathrm{SO}_{4}^{2-}-\mathrm{S}$ & 9.1 & 2.9 & 15 & 4.9 & 3.3 & 1.0 \\
\hline
\end{tabular}

$(1.5 \mathrm{~km})$ in the $\mathrm{NW}$ may have contributed to the $\mathrm{NH}_{3}$, but not significantly to the $\mathrm{NH}_{4}^{+}$concentration (Fig. 1c). The transport time was possibly too fast for gas-particle-conversion to be effective. The concentration of $\mathrm{HNO}_{3}$ showed a peak in the $\mathrm{SW}$, where the $\mathrm{SO}_{2}$ concentration was also largest (not shown). This correlation suggests photochemical production of $\mathrm{HNO}_{3}$ from $\mathrm{NO}_{\mathrm{x}}$, which, like $\mathrm{SO}_{2}$, originates from industrial and combustion sources.

\subsection{Biosphere-atmosphere exchange of aerosols}

\subsubsection{Measured apparent particle deposition velocities}

Counting statistics were too poor for a rigorous spectral analysis of the aerosol (co-) spectra to be carried out, but nevertheless the particle number fluxes measured by EC with the ASASP-x OPC show regular patterns. Deposition velocities for fine particles $\left(0.1 \mu \mathrm{m}<D_{p}<0.5 \mu \mathrm{m}\right)$ range from $<0.5 \mathrm{~mm} \mathrm{~s}^{-1}$ at night to nearly $10 \mathrm{~mm} \mathrm{~s}^{-1}$ during daytime, and on various days $V_{d s}$ increased with particle size within the measured size range (Figs. 2a, 6d). The magnitude of $V_{d s}$ is larger than derived from theoretical considerations (e.g. Slinn, 1982), wind tunnel studies (e.g. Chamberlain, 1966) and also somewhat larger than recent micrometeorological measurements of deposition velocities to short vegetation. For the size range considered here, Nemitz et al. (2002) derived maximum daytime deposition velocities of 2 to $2.5 \mathrm{~mm} \mathrm{~s}^{-1}$ to Scottish moorland vegetation, with an overall average $<1 \mathrm{~mm} \mathrm{~s}^{-1}$. Gallagher et al. (2002) reported an average $V_{d s}$ of 1.1 and $0.9 \mathrm{~mm} \mathrm{~s}^{-1}$ to tall and short grass, respectively $\left(0.1<D_{p}<0.2 \mu \mathrm{m}\right)$, while for $0.52 \mu \mathrm{m}$ particles, Vong et al. (2004) derived average deposition velocities of 3,2 and $5 \mathrm{~mm} \mathrm{~s}^{-1}$ during neutral, stable and unstable conditions, respectively. It is possible that the morphology of heather is comparably efficient in collecting aerosols, but the somewhat large average $V_{d}$ found at Elspeet were probably a consequence of the strong increase in $V_{d}$ during unstable conditions, which often occurred during the warm measurement period. This increase is qualitatively consistent with former observations (Wesely et al., 1985; Vong et al., 2004).
Interestingly, in neutral conditions ( $1 / L=0$ in Fig. 3$), V_{d}$ appeared to be insensitive to particle diameter over the sizerange of the measurements.

At Elspeet, during some daytime periods, especially in the afternoon, apparent particle emission was observed at the measurement height for the smallest size classes $\left(D_{p}<0.18 \mu \mathrm{m}\right)$, while larger particles were continuously deposited (Figs. 2b, 6d, 7d). As a result $V_{d s}$ normalized by $u_{*}$ (Fig. 3) shows significant negative divergence from the expected functional relationship on the stability parameter for $L^{-1}<-0.07 \mathrm{~m}^{-1}(-14 \mathrm{~m}<L<0 \mathrm{~m})$. Apparent emission fluxes therefore coincided with unstable conditions, which are mainly found during warm daytime periods. However, a parameterization of the form suggested by Wesley et al. (1985) may still be estimated from periods during which mostly deposition was observed (Eq. 12).

The deposition velocities of $\mathrm{NH}_{4}^{+}$as inferred from the SJAC gradient measurements (Fig. 4) show similarly small values at night, but large values in excess of $10 \mathrm{~mm} \mathrm{~s}^{-1}$ during some daytime conditions. These appear to be inconsistent with the small size of $\mathrm{NH}_{4}^{+}$aerosol and the $V_{d}$ simultaneously derived from the EC measurements. The average deposition velocity of $2.0 \mathrm{~mm} \mathrm{~s}^{-1}$ (daytime: 2.7 ; nighttime: $0.8 \mathrm{~mm} \mathrm{~s}^{-1}$ ) agrees well with the value of $1.8 \mathrm{~mm} \mathrm{~s}^{-1}$ previously observed for $\mathrm{NH}_{4}^{+}$deposition above heathland (Duyzer, 1994). By contrast, much larger $\mathrm{NH}_{4}^{+}$deposition velocities have been found over forest, with averages ranging from 11 to $23 \mathrm{~mm} \mathrm{~s}^{-1}$ (Wyers and Duyzer, 1997; Rattray and Sievering, 2001).

\subsubsection{Dry deposition inputs}

Dry deposition estimates for the measurement period of $\mathrm{N}$ and $\mathrm{S}$ are summarized in Table 5, based on the assumption that the deposition rate of the anions equals that of $\mathrm{NH}_{4}^{+}$. Without the contribution of $\mathrm{NO}_{2}$ and PAN, the total $\mathrm{N}$ dry deposition measured during this period would be equivalent to a yearly total of $18.5 \mathrm{~kg} \mathrm{~N} \mathrm{ha}^{-1} \mathrm{yr}^{-1}$, with a contribution of $\mathrm{NH}_{4}^{+}$and $\mathrm{NO}_{3}^{-}$aerosol of $19 \%$ overall and of $25 \%$ during the day. Nitric acid, the concentration of which (as $\mathrm{N}$ ) was $6.6 \%$ 
of the $\mathrm{NH}_{3}-\mathrm{N}$ concentration at this site (cf. Fig. 1), makes only a minor $(6 \%)$ contribution to the overall dry deposition. This is in contrast to sites with a less alkaline pollution climate, where $\mathrm{HNO}_{3}$ may dominate $\mathrm{N}$ dry deposition (e.g. Rattray and Sievering, 2001). These dry deposition values may be compared with former bulk deposition measurements, which derived additional annual deposition of $11.8 \mathrm{~kg} \mathrm{NH}_{4}^{+}$$\mathrm{Nha}^{-1} \mathrm{yr}^{-1}$ and $5.3 \mathrm{~kg} \mathrm{NO}_{3}^{-}-\mathrm{Nha}^{-1} \mathrm{yr}^{-1}$ (Erisman et al., 1994). Thus, $\mathrm{NH}_{\mathrm{x}}$ deposition is dominated by $\mathrm{NH}_{3}$ dry deposition, while the $\mathrm{NO}_{3}^{-}$deposition is dominated by wet deposition.

\subsubsection{Apparent particle emission - a measurement artefact?}

Flux measurements derived from parameters that change with $T$ and $h$ need to be corrected for sensible and latent heat fluxes (Webb et al., 1980). Such a parameter is the particle radius, which is determined by water uptake in equilibrium with ambient humidity (Fairall, 1984; Kowalski, 2001). Unlike some other optical particle counters, the ASASP-x is thought to dry out the particles and thus measures the dry particle size, which is a conserved parameter (Gallagher et al., 1997).

Sample inlet imperfections are a common error source for particle sampling, especially for super-micron and nanometre particles, but it is unlikely that they should systematically affect measurements at certain times of the day. Finally, electrophoretic effects are also an unlikely cause: apparent particle emission was observed during cloudless skies, when the magnetic potential of the atmosphere is small. Fontan et al. (1997) attributed observations of particle emission to lowfrequency contamination of the power-spectra and found that any emission events were removed by high-pass filtering. As mentioned before, poor sampling statistics hampered a general spectral analysis. However, high-pass filtering as recommended by Fontan et al. was applied and had very little effect on the particle fluxes. The aerosol sampler by Fontan et al. measured the flux of the bulk aerosol with a size mainly between 0.05 and $0.5 \mu \mathrm{m}$, and therefore apparent emission (or growth) of the particles in a certain size-class might have been masked by the deposition of others. The observation of negative particle deposition velocities by the ASASP-x EC measurements is therefore almost certainly not the result of a physical measurement artefact.

4.3 The effect of gas-to-particle conversion on flux measurements at Elspeet

Semi-natural surfaces have been shown to occasionally emit $\mathrm{NH}_{3}$ and provide a non-zero surface uptake resistance for $\mathrm{HNO}_{3} / \mathrm{HCl}$ (e.g. Huebert et al., 1988; Erisman and Wyers, 1993; Neftel et al., 1996; Sutton et al., 1998; Nemitz et al., 2000). In general, however, concentrations, and therefore $K_{m}$ decline towards the ground, while $K_{e}$ is increased above warm vegetation. As a result, the ratio $K_{m} / K_{e}$ is greatly low- ered near the ground, as observed at Elspeet. In the presence of $\mathrm{NH}_{4} \mathrm{NO}_{3}$ and $\mathrm{NH}_{4} \mathrm{Cl}$, aerosol evaporation leads to the observation of apparent fast deposition of $\mathrm{NH}_{4}^{+}, \mathrm{NO}_{3}^{-}$ and $\mathrm{Cl}^{-}$, apparent slow deposition or even emission of $\mathrm{HNO}_{3}$ and $\mathrm{HCl}$, as well as an underestimation of the $\mathrm{NH}_{3}$ surface deposition by aerodynamic gradient methods. Moreover, the modelling of the height-dependent size-distribution of $\mathrm{NH}_{4} \mathrm{NO}_{3}$ aerosol as modified by the $\mathrm{HNO}_{3}-\mathrm{NH}_{3}-\mathrm{NH}_{4} \mathrm{NO}_{3}$ equilibrium by Nemitz and Sutton (2004) demonstrates that bi-directional particle number fluxes may result from this interaction, with small particles (typically $D_{p}<0.15-0.2 \mu \mathrm{m}$ ) showing apparent emission. This is conditional on two factors: the measurements must be carried out below the theoretical height at which equilibrium would be attained and $\mathrm{NH}_{4}^{+}$must be contained in a large fraction of the particles. The absolute error of $\mathrm{NH}_{4}^{+}$evaporation on the fluxes depends on the chemical time-scale, governed by the aerosol concentration, and the absolute divergence from equilibrium. By contrast, the relative effect is dominated by the magnitude of the fluxes and is usually larger for slowly depositing $\mathrm{NH}_{4}^{+}$ aerosol than for acid gases and $\mathrm{NH}_{3}$, which are usually exchanged at a higher rate.

Three existing datasets, two of which were obtained above semi-natural vegetation in the Netherlands, provide evidence that $\mathrm{NH}_{4}^{+}$evaporation can indeed have a significant effect on surface exchange fluxes, and also allow the effect to be quantified:

1. Boulder Atmospheric Observatory, Colorado. From gradient measurements carried out in the vicinity of local $\mathrm{NH}_{3}$ sources, Huebert et al. (1988) derived higher values of $V_{d}$ for $\mathrm{NO}_{3}^{-}$than they found for $\mathrm{SO}_{4}^{2-}$ aerosol and sometimes even than for $\mathrm{HNO}_{3}$, which occasionally showed apparent emission gradients. Brost et al. (1988) qualitatively modelled the phenomena and concluded that $\mathrm{NH}_{4} \mathrm{NO}_{3}$ evaporation was a likely explanation for the anomalies.

2. Dutch heathland "Leende Heide". At Leende Heide bi-directional aerosol fluxes were found to be related to the observation of $\mathrm{NH}_{3}$ emission (Gallagher et al., 1993), while Zhang et al. (1995) observed apparent $\mathrm{HNO}_{3}$ emission. These authors derived a first order correction for the $\mathrm{NH}_{3}$ flux of about $50-200 \mathrm{ng} \mathrm{m}^{-2} \mathrm{~s}^{-1}$ at daytime, which often represented about 5-20\% of the flux, but even caused flux reversal when the $\mathrm{NH}_{3}$ flux was small. However, this correction was based on the assumption that at the surface $\mathrm{HNO}_{3}$ deposits at $V_{\text {max }}$, and may be an overestimate (cf. Nemitz et al., 2004).

3. Dutch forest "Speulderbos". Wyers and Duyzer (1997) observed $\mathrm{NO}_{3}^{-}$deposition fluxes faster than permitted by turbulence $\left(V_{d}>R_{a}^{-1}\right)$ to the coniferous forest "Speulderbos", NL, while $\mathrm{SO}_{4}^{2-}$ showed smaller gradients. Single runs of this dataset were assessed using a numerical model, and the modified concentration 
gradients showed a better fit to the measurements than log-linear profiles (Van Oss et al., 1998). In the light of the new investigations into the effect of $\mathrm{NH}_{4}^{+}$evaporation on size-segregated particle number fluxes presented by Nemitz and Sutton (2004), these results are also consistent with the simultaneous observation of apparent emission of small particles $\left(0.10<D_{p}<0.18 \mu \mathrm{m}\right)$ reported by Gallagher et al. (1997). Unfortunately, gradients of $\mathrm{HNO}_{3}$ and $\mathrm{HCl}$ were not measured at Speulderbos. The modelling by van Oss et al. (1998) indicated differences between fluxes of $\mathrm{NH}_{3}$ derived under the constant flux assumption and "corrected" for chemical reactions of 20 to $250 \mathrm{ng} \mathrm{m}^{-2} \mathrm{~s}^{-1}$. These authors pointed out that the $\mathrm{NH}_{3}$ emissions occasionally observed at Speulderbos (Duyzer et al., 1992; Wyers and Erisman, 1998) may partly have been an artefact caused by this $\mathrm{NH}_{4}^{+}$evaporation. If all $\mathrm{NH}_{3}$ emission were due to this effect the overestimation of the flux would frequently have to be as high as $100 \mathrm{ng} \mathrm{m}^{-2} \mathrm{~s}^{-1}$. It should be noted, however, that both cuticular desorption and stomatal emission are likely to account for some of the observed $\mathrm{NH}_{3}$ emission (Wyers and Erisman, 1998).

\subsubsection{Strong evidence for $\mathrm{NH}_{4}^{+}$evaporation at Elspeet}

At Elspeet four independent observations suggest that during the day volatile $\mathrm{NH}_{4}^{+}$salts evaporated and modified the gradients of gaseous $\mathrm{NH}_{3}, \mathrm{HNO}_{3}$ and $\mathrm{HCl}$ as well as $\mathrm{NH}_{4}^{+}$ aerosol, and this study therefore provides more conclusive evidence than previous measurements:

1. For $\mathrm{HNO}_{3}$ and $\mathrm{HCl}, V_{d}$ derived by the gradient method was significantly smaller than $V_{\max }$ (Figs. 6 and 7), which is in agreement with the release of these acidic gases from aerosol near the surface (Nemitz et al., 2004).

2. Large apparent values of $V_{d}$ were inferred from $\mathrm{NH}_{4}^{+}$ gradients during some periods, as it would have been the case if $\mathrm{NH}_{4}^{+}$had evaporated during deposition (Figs. 4, $6 b$ and $7 c)$.

3. $K_{m}$ was usually smaller than $K_{e \text {,pure providing potential }}$ for aerosol volatilization. The extrapolation of gradients of the gas concentrations as well as $T$ and $h$ to a notional height of $50 \mathrm{~m}$ indicates that concentrations well above the surface were more likely to be in thermodynamic equilibrium than near the ground. Although the correct value of $K_{e}$ is uncertain, this indicates that the deposition process led to $K_{m} \ll K_{e}$ near the surface (Nemitz, 1998).

4. The EC flux measurements of small particles $\left(D_{p}<0.18 \mu \mathrm{m}\right)$ cover periods of reduced $V_{d s}$ or even apparent emission. Intuitively this observation may be attributed to condensation and particle growth.
The modelling exercise of Nemitz and Sutton (2004) shows that, if $K_{m}<K_{e}$ near the surface, particle evaporation may lead to an increased number of small particles at lower heights and apparent emission fluxes, although all particles are physically deposited. Together with (3) the observation of bi-directional size-dependent particle fluxes is therefore consistent with $\mathrm{NH}_{4}^{+}$evaporation.

The above phenomena were temporally correlated as demonstrated in Figs. 6 and 7 and this provides additional evidence that the anomalies in the flux measurements at Elspeet were caused by $\mathrm{NH}_{4}^{+}$evaporation. The modification of surface exchange fluxes by $\mathrm{NH}_{4}^{+}$evaporation is consistent with the time-scale analysis (Table 4 and Fig. 5). Chemical timescales estimated from the aerosol surface area are mainly in the range of 1-8 $\mathrm{min}$ and therefore in general shorter than found at a clean Scottish site (Nemitz et al., 2000), but comparable with the values reported for sites in Eastern Germany (Kins et al., 1996; Seidl et al., 1996). As a result, at Elspeet gpic was often expected to be sufficiently fast to cause significant flux divergence for $u_{*}<0.12 \mathrm{~m} \mathrm{~s}^{-1}$, a situation which arose frequently between 29 May and 12 June 1996. As pointed out by Nemitz et al. (2000), this kind of analysis only compares the chemical time-scale with the turbulent diffusive time-scale above the canopy, while diffusive transport within the canopy is much slower providing ample time for chemical conversion to occur.

\subsubsection{Magnitude of the effect of gpic on flux measurements} and the atmospheric lifetime of reduced nitrogen

A first-order correction of the $\mathrm{NH}_{3}$ flux may be obtained from the comparison of the $\mathrm{NH}_{4}^{+}$flux derived from gradient measurements with expected values (Fig. 7a). During some warm daytime periods the aerodynamic gradient technique underestimates the $\mathrm{NH}_{3}$ deposition flux by as much as $20 \mathrm{ng} \mathrm{m}^{-2} \mathrm{~s}^{-1}$ ( $16 \mathrm{ng} \mathrm{N} \mathrm{m}^{-2} \mathrm{~s}^{-1}$ ). Considering the average daytime $\mathrm{NH}_{3}-\mathrm{N}$ flux of $41 \mathrm{ng} \mathrm{N} \mathrm{m}^{-2} \mathrm{~s}^{-1}$ this is a considerable effect on the $\mathrm{NH}_{3}$ flux, but it constitutes an even larger relative error for the fluxes of $\mathrm{NH}_{4}^{+}$and $\mathrm{HNO}_{3}$. This error estimate is in general agreement with the modelling, which, for an example day with high $\mathrm{HNO}_{3}$ concentrations, indicates average errors of $28 \%$ and $8.5 \%$ for the fluxes of $\mathrm{NH}_{3}$ and $\mathrm{HNO}_{3}$, respectively. By contrast, Zhang et al. (1995) derived corrections of up to $100 \mathrm{ng} \mathrm{m}^{-2} \mathrm{~s}^{-1}$ from upward gradients of $\mathrm{HNO}_{3}$, which they also attributed to $\mathrm{NH}_{4} \mathrm{NO}_{3}$ evaporation. Consequently, surface exchange fluxes of $\mathrm{NH}_{3}$, but also of $\mathrm{NH}_{4}^{+}$and the acids, measured under these conditions, need to be calculated using modified gradient-techniques, which account for the chemical conversions (Brost et al., 1988; Kramm and Dlugi, 1994; Nemitz et al., 1996; Van Oss et al., 1998; Nemitz and Sutton, 2004). Given the current uncertainties in $K_{e}$ and the chemical time-scale (or sticking 
coefficient), this cannot yet be done on a systematic basis and here more investigations are urgently needed.

The flux modification through gpic would propagate to the parameterisations derived from the uncorrected $\mathrm{NH}_{3}$ fluxes (Nemitz et al., 2004). In particular, evaporation of volatile $\mathrm{NH}_{4}^{+}$salts, either airborne and on leaf surfaces, may provide a second $\mathrm{NH}_{3}$ emission source in addition to stomatal emission or inhibit deposition to the canopy. This would result in an overestimation of the non-dimensional stomatal compensation point $(\Gamma)$ during daytime and of the cuticular resistance $\left(R_{w}\right)$ during night.

This study demonstrates that size-segregated particle flux measurements are modified, not only by water vapour fluxes (Kowalski, 2001), but also by condensational particle growth and aerosol evaporation. Both effects need to be considered when interpreting measurement derived estimates of $V_{d}\left(D_{p}\right)$, especially for fine particles. Areas with high concentrations of volatile aerosol components or strong emissions of biogenic aerosol precursor gases should be avoided for studies deriving deposition velocities from eddycovariance measurements. By contrast, flux measurements provide a powerful tool for estimating particle growth or evaporation rates within the uncertainties of the flux measurements themselves.

It should be noted that most of the effects of $\mathrm{NH}_{4} \mathrm{NO}_{3}$ evaporation are not always observed at Elspeet, but are confined to warm and dry conditions. Although the error of aerosol evaporation on the $\mathrm{HNO}_{3}$ flux is substantial, it is therefore not sufficient to explain the divergence of $V_{d}$ from $V_{\max }$ on all days in full. Here an additional surface uptake resistance, caused by a non-zero vapour pressure above deposited salts on leaf surfaces, could provide a further explanation. Aerosol evaporation may also have contributed to the very large $\mathrm{NH}_{3}$ emission fluxes of up to $550 \mathrm{ng} \mathrm{m}^{-2} \mathrm{~s}^{-1}$, which had been previously observed at Elspeet (Erisman and Wyers, 1993; Sutton et al., 1995), but not repeated during the campaign presented (Nemitz et al., 2004).

The measurements presented here suggest evaporation rates of about $10-100 \mu \mathrm{g} \mathrm{NH}_{4} \mathrm{NO}_{3} \mathrm{~m}^{-3} \mathrm{~h}^{-1}$ in the surface layer. Assuming (i) a typical daytime boundary layer height of $1000 \mathrm{~m}$, (ii) chemical conversions to be confined to the lowest $50 \mathrm{~m}$ and (iii) an average $\mathrm{NH}_{4} \mathrm{NO}_{3}$ concentration of $5 \mu \mathrm{g} \mathrm{m}^{-3}$, this conversion rate equates to an average removal rate of $3 \times 10^{-6}$ to $3 \times 10^{-5} \mathrm{~s}^{-1}$ for the boundary layer (or an atmospheric residence time of 9 to $90 \mathrm{~h}$ ), somewhat lower than the values of $1 \times 10^{-4} \mathrm{~s}^{-1}$ and $4 \times 10^{-5} \mathrm{~s}^{-1}$ proposed by Erisman et al. (1988) for day and night-time conditions, respectively. For comparison, atmospheric life-times due to removal by dry deposition $\left(\tau_{V d}\right)$ may be approximated by the ratio of boundary-layer height and $V_{d}$ (Moeller and Schieferdecker, 1985; Sutton, 1990). Typical daytime values of $\tau_{V d}$ at Elspeet would be $100 \mathrm{~h}$ for $\mathrm{NH}_{4}^{+}$and $15 \mathrm{~h}$ for $\mathrm{NH}_{3}$. Therefore the evaporation of volatile $\mathrm{NH}_{4}^{+}$over semi-natural surfaces will significantly reduce its overall lifetime in the tropo- sphere, as well as lower the lifetime of total $\mathrm{NH}_{\mathrm{x}}$ by increasing the fraction which can be dry deposited as $\mathrm{NH}_{3}$. Flechard and Fowler (1998) suggested that the effective mixing height for $\mathrm{NH}_{3}$ may be reduced compared with the boundary-layer height as $\mathrm{NH}_{3}$ is derived from surface sources and decreases away from the surface. This effect would reduce the absolute values but not the ratio of the residence times.

From the relatively short chemical lifetime of volatile $\mathrm{NH}_{4}^{+}$above warm semi-natural vegetation, it is likely that after long travel in dry remote locations $\mathrm{NH}_{4}^{+}$aerosol will be transported mainly as $\left(\mathrm{NH}_{4}\right)_{2} \mathrm{SO}_{4}$, while a large fraction of the $\mathrm{NO}_{3}^{-}$will eventually be present as $\mathrm{NaNO}_{3}$. Thus the transport distance of $\mathrm{NH}_{4}^{+}$should be sensitive and positively correlated to $\mathrm{SO}_{4}^{2-}$ concentrations, while the transport distance of $\mathrm{NO}_{3}^{-}$should be larger in humid maritime climates.

\section{Conclusions}

Aerosol number flux measurements of fine particles $\left(0.1<D_{p}<0.5 \mu \mathrm{m}\right)$ by eddy-covariance (EC) showed surface deposition velocities $\left(V_{d s}\right)$ of $<0.5 \mathrm{~mm} \mathrm{~s}^{-1}$ during night, but values of up to $10 \mathrm{~mm} \mathrm{~s}^{-1}$ during the day, faster than those found during other recent studies over short vegetation, probably due to the observed strong increase in unstable conditions. A $V_{d s}$ parameterization is presented for these particles as a function of particle size, turbulence and atmospheric stability. Average values of $V_{d s}\left(\mathrm{NH}_{4}^{+}\right)$derived by a gradient technique (overall $2.0 \mathrm{~mm} \mathrm{~s}^{-1}$; daytime: 2.7 ; night-time $0.8 \mathrm{~mm} \mathrm{~s}^{-1}$ ) are similar to previous measurements. Using the uncorrected fluxes, $\mathrm{NH}_{4}^{+}$and $\mathrm{NO}_{3}^{-}$deposition contribute $19 \%$ to the total $\mathrm{N}$ dry deposition measured.

The EC technique also inferred emission of particles $<0.18 \mu \mathrm{m}$ on several afternoons, while $V_{d s}\left(\mathrm{NH}_{4}^{+}\right)$significantly exceed the EC values during these days. These phenomena are correlated with reduced deposition rates of atmospheric acids and $\mathrm{NH}_{3}$ reported in a companion paper, strongly suggesting that surface exchange fluxes were affected by volatilization of $\mathrm{NH}_{4} \mathrm{NO}_{3}$ aerosol. This is consistent with the estimate of short chemical time-scales ( $<4 \mathrm{~min})$ for many daytime periods and with the observation of surface gas phase concentration well below the dissociation constant of pure $\mathrm{NH}_{4} \mathrm{NO}_{3}$.

It is estimated that aerosol evaporation leads to a substantial overestimation of the $\mathrm{NH}_{3}$ flux of $20 \mathrm{ng} \mathrm{m}^{-2} \mathrm{~s}^{-1}$ during the day and an equivalent value for $\mathrm{HNO}_{3}$. This cannot completely explain the departure of $V_{d}$ from $V_{\max }$ found for the acids, which would imply the presence of a non-zero surface uptake resistance for $\mathrm{HNO}_{3}$ and $\mathrm{HCl}$.

It is concluded that $\mathrm{NH}_{4}^{+}$evaporation may lead to a significant underestimation of $\mathrm{NH}_{3}$ deposition to semi-natural vegetation during daytime by current measurements and models where this process is not adequately treated. This is particularly true if measurements are carried out in areas where large aerosol concentrations lead to short chemical time-scales and 
where large concentration of volatile $\mathrm{NH}_{4} \mathrm{NO}_{3}$ and $\mathrm{NH}_{4} \mathrm{Cl}$ are present. These conditions are fulfilled above semi-natural vegetation in the vicinity of high $\mathrm{NH}_{3}$ emission densities, common in the Netherlands and other areas with high livestock densities. At large $\mathrm{NH}_{3}$ concentrations the underestimation during daytime may be as high as $100 \mathrm{ng} \mathrm{m}^{-2} \mathrm{~s}^{-1}$, although a value of $20 \mathrm{ng} \mathrm{m}^{-2} \mathrm{~s}^{-1}$ as estimated for Elspeet is probably more representative.

Acknowledgements. The authors received EU funding through the projects EXAMINE and GRAMINAE, with national contributions from the UK Department of Environment, Transport and the Regions as well as from the Dutch ministry for Spatial Planning and the Environment. Access to the field site was kindly provided by the municipal authorities of Elspeet. We thank Ü. Rannik for his very detailed, insightful and constructive referee comments.

Edited by: M. Ammann

\section{References}

Brost, R. A., Delany, A. C., and Huebert, B. J.: Numerical Modeling of Concentrations and Fluxes of $\mathrm{HNO}_{3}, \mathrm{NH}_{3}$, and $\mathrm{NH}_{4} \mathrm{NO}_{3}$ near the Surface, J. Geophys. Res.-Atmos., 93, D6, 7137-7152, 1988.

Chamberlain, A. C.: Transport of gases to and from grass and grasslike surfaces, Proceedings of the Royal Society A, 290, 236-265, 1966.

Dammgen, U. and Zimmerling, R.: Vertical fluxes of air-borne acidifying and eutrophying species in the Schorfheide Nature Reserve in Brandenburg, Germany, Journal of Applied BotanyAngewandte Botanik, 76, 5-6, 190-202, 2002.

Duan, B., Fairall, C. W., and Thomson, D. W.: Eddy-covariance measurements of the dry deposition of particles in wintertime, Journal of Applied Meteorology, 28, 642-652, 1988.

Duyzer, J.: Dry Deposition of Ammonia and Ammonium Aerosols over Heathland, J. Geophys. Res.-Atmos., 99, D9, $18757-$ $18763,1994$.

Duyzer, J. H., Verhagen, H. L. M., Weststrate, J. H., and Bosveld, F. C.: Measurement of the dry deposition flux of $\mathrm{NH}_{3}$ on to coniferous forest, Environmental Pollution, 75, 3-13, 1992.

Erisman, J. W. and Wyers, G. P.: Continuous Measurements of Surface Exchange of $\mathrm{SO}_{2}$ and $\mathrm{NH}_{3}$ - Implications for Their Possible Interaction in the Deposition Process, Atmos. Environ. Part a General Topics, 27, 13, 1937-1949, 1993.

Erisman, J. W., Vermetten, A. W. M., Asman, W. A. H., WaijersIjpelaan, A., and Slanina, J.: Vertical distribution of gases and aeorsols: the behaviour of ammonia and related components in the lower atmosphere, Atmos. Environ., 22, 1153-1160, 1988.

Erisman, J. W., Vanelzakker, B. G., Mennen, M. G., Hogenkamp, J., Zwart, E., Vandenbeld, L., Romer, F. G., Bobbink, R., Heil, G., Raessen, M., Duyzer, J. H., Verhage, H., Wyers, G. P., Otjes, R. P., and Mols, J. J.: The Elspeetsche Veld Experiment on Surface Exchange of Trace Gases 00 Summary of Results, Atmos. Environ., 28, 3, 487-496, 1994.

Fairall, C. W.: Interpretation of Eddy-Correlation Measurements of Particulate Deposition and Aerosol Flux, Atmos. Environ., 18, 7, 1329-1337, 1984.
Fitzjarrald, D. R. and Lenschow, D. H.: Mean concentration and flux profiles for chemically reactive species in the atmospheric surface layer, Atmos. Environ., 17, 2505-2512, 1983.

Flechard, C. R. and Fowler, D.: Atmospheric ammonia at a moorland site, II: Long-term surface-atmosphere micrometeorological flux measurements, Quarterly Journal of the Royal Meteorological Society, 124, 547, 759-791, 1998.

Foken, T., Dlugi, R., and Kramm, G.: On the determination of dry deposition and emission of gaseous compounds at the biosphereatmosphere-interface, Meteorologische Zeitschrift, 4, 91-118, 1995.

Fontan, J., Lopez, A., Lamaud, E., and Druilhet, A.: Vertical flux measurements of the submicronic aerosol particles and parameterization of the dry deposition velocity, in Biosphereatmosphere exchange of pollutants and trace substances, Transport and Chemical Transformation of Pollutants in the Troposphere, edited by Slanina, J., Springer Verlag, Heidelberg, Germany, 381-390, 1997.

Gallagher, M. W., Choularton, T. W., Wicks, A., Beswick, K. M., Coe, H., Sutton, M., Fowler, D., Duyzer, J. H., and Wyers, P.: Measurements of aerosol exchange to a Dutch heather moor, In: Proceedings of the EUROTRAC Symposium '92, GarmischPartenkirchen, edited by Borrell, P. M., Borrell, P., Cavitas, T., and Seiler, W., Germany, SPB Academic Publishing b.v., The Hague, 694-698, 1993.

Gallagher, M. W., Beswick, K. M., Duyzer, J., Westrate, H., Choularton, T. W. and Hummelshoj, P.: Measurements of aerosol fluxes to Speulder forest using a micrometeorological technique, Atmos. Environ., 31, 3, 359-373, 1997.

Gallagher, M. W., Nemitz, E., Dorsey, J. R., Fowler, D., Sutton, M. A., Flynn, M., and Duyzer, J.: Measurements and parameterizations of small aerosol deposition velocities to grassland, arable crops and forest: Influence of surface roughness length on deposition, J. Geophys. Res.-Atmos., 107, D12, 2002.

Garland, J. A.: On the size dependence of particle deposition, Water Air and Soil Pollution: Focus, 1, 5-6, 323-332, 2001.

Hanson, P. J. and Lindberg, S. E.: Dry Deposition of Reactive Nitrogen-Compounds - a Review of Leaf, Canopy and NonFoliar Measurements, Atmos. Environ. Part a - General Topics, 25, 8, 1615-1634, 1991.

Harrison, R. M. and Kitto, A. M. N.: Field Intercomparison of Filter Pack and Denuder Sampling Methods for Reactive Gaseous and Particulate Pollutants, Atmos. Environ. Part a - General Topics, 24, 10, 2633-2640, 1990.

Huebert, B. J., Luke, W. T., Delany, A. C., and Brost, R. A.: Measurements of Concentrations and Dry Surface Fluxes of Atmospheric Nitrates in the Presence of Ammonia, J. Geophys. Res.Atmos., 93, D6, 7127-7136, 1988.

Katen, P. C. and Hubbe, J. M.: An evaluation of optical particle counter measurements of the dry deposition of atmospheric aerosol particles, J. Geophys. Res.-Atmos., 90, 2145-2160, 1985.

Khlystov, A., Wyers, G. P., and Slanina, J.: The steam-jet aerosol collector, Atmos. Environ., 29, 17, 2229-2234, 1995.

Kins, L., Seidl, W., Schween, J., and Dlugi, R.: The chemical behaviour and deposition of ammonia, ammonium nitrate and nitric acid. In: International conference on atmospheric ammonia, edited by Sutton, M. A., Lee, D. S., Dollard, G., and Fowler, D., Institute of Terrestrial Ecology (ITE), Edinburgh, Oxford, United 
Kingdom, 94-97, 1996.

Kowalski, A. S.: Deliquescence induces eddy covariance and estimable dry deposition errors, Atmos. Environ., 35, 28, 4843 4851, 2001.

Kramm, G. and Dlugi, R.: Modelling of the vertical fluxes of nitric acid, ammonia and ammonium nitrate, J. Atmos. Chem., 319357, 1994.

Moeller, D. and Schieferdecker, H.: A relationship between agricultural $\mathrm{NH}_{3}$ emissions and the atmospheric $\mathrm{SO}_{2}$ content over industrial areas, Atmos. Environ., 19, 695-700, 1985.

Monteith, J. L. and Unsworth, M. H.: Principles of environmental physics, Arnold Press, London, United Kingdom, 291, 1990.

Mozurkewich, M.: The dissociation constant of ammonium nitrate and its dependence on temperature, relative humidity and particle size, Atmos. Environ., 27, 261-270, 1993.

Neftel, A., Blatter, A., Hesterberg, R., and Staffelbach, T.: Measurements of concentration gradients of $\mathrm{HNO}_{2}$ and $\mathrm{HNO}_{3}$ over a semi-natural ecosystem, Atmos. Environ., 30, 17, 3017-3025, 1996.

Nemitz, E.: Surface/atmosphere exchange of ammonia and chemically interacting species, Ph. D. Thesis, UMIST, Manchester, 1998.

Nemitz, E. and Sutton, M. A.: Gas-particle interactions above a Dutch heathland: III. Modelling the influence of the $\mathrm{NH}_{3}$ $\mathrm{HNO}_{3}-\mathrm{NH}_{4} \mathrm{NO}_{3}$ equilibrium on size-segregated particle fluxes, Atmos. Chem. Phys. Discuss., 4, 1567-1621, 2004.

Nemitz, E., Sutton, M. A., Fowler, D., and Choularton, T. W.: Application of a $\mathrm{NH}_{3}$ gas-to-particle conversion model to measurement data. In: International conference on atmospheric ammonia, edited by Sutton, M. A., Lee, D. S., Dollard, G., and Fowler, D., Institute of Terrestrial Ecology (ITE), Edinburgh, Oxford, United Kingdom, 2-4 Oct. 1995, 98-103, 1996.

Nemitz, E., Sutton, M. A., Wyers, G. P., Otjes, R. P., Schjoerring, J. K., Gallagher, M. W., Parrington, J., Fowler, D., and Choularton, T. W.: Surface/atmosphere exchange and chemical interaction of gases and aerosols over oilseed rape, Agricultural and Forest Meteorology, 105, 4, 427-445, 2000.

Nemitz, E., Flynn, M., Williams, P. I., Milford, C., Theobald, M. R., Blatter, A., Gallagher, M. W., and Sutton, M. A.: A relaxed eddy accumulation system for the automated measurement of atmospheric ammonia fluxes, Water Air and Soil Pollution: Focus, 1, 189-202, 2001.

Nemitz, E., Gallagher, M. W., Duyzer, J. H., and Fowler, D.: Micrometeorological measurements of particle deposition velocities to moorland vegetation, Quarterly Journal of the Royal Meteorological Society, 128, 2281-2300, 2002.

Nemitz, E., Sutton, M. A., Wyers, G. P., and Jongejan, P. A. C.: Gas-particle interactions above a Dutch heathland: I. Surface exchange fluxes of $\mathrm{NH}_{3}, \mathrm{SO}_{2}, \mathrm{HNO}_{3}$ and $\mathrm{HCl}$, Atmos. Chem. Phys. Discuss., 4, 1473-1517, 2004.

Neumann, H. H. and den Hartog, G.: Eddy-covariance measurements of atmospheric fluxes of ozone, sulphur and particulates during the Champaign intercomparison study, J. Geophys. Res.Atmos., 90, D1, 2097-2110, 1985.

Oms, M. T., Jongejan, P. A. C., Veltkamp, A. C., Wyers, G. P., and Slanina, J.: Continuous monitoring of atmospheric $\mathrm{HCl}, \mathrm{HNO}_{2}$, $\mathrm{HNO}_{3}$, and $\mathrm{SO}_{2}$, by wet-annular denuder air sampling with online chromatographic analysis, Int. J. Env. Anal. Chem., 62, 3, 207-218, 1996.
Peters, K. and Eiden, R.: Modelling the dry deposition velocity of aerosol particles to a spruce forest, Atmos. Environ., 26A, 14, 2555-2564, 1992.

Pio, C. A. and Harrison, R. M.: Vapour pressure of ammonium chloride aerosol: effect of temperature and humidity, Atmos. Environ., 21, 2711-2715, 1987.

Press, W. H., Flannery, B. P., Teukolsky, S. A., and Vetterling, W. T.: Numerical recipes in Pascal - the art of scientific computing, Cambridge University Press, Cambridge, United Kingdom, 759, 1989.

Rattray, G. and Sievering, H.: Dry deposition of ammonia, nitric acid, ammonium, and nitrate to alpine tundra at Niwot Ridge, Colorado, Atmos. Environ., 35, 1105-1109, 2001.

Ruijgrok, W., Tieben, H., and Eisinga, P.: The dry deposition of particles to a forest canopy: a comparison of model and experimental results, Atmos. Environ., 31, 3, 399-415, 1997.

Sanz, M. J., Carratala, A., Gimeno, C., and Millan, M. M.: Atmospheric nitrogen deposition on the east coast of Spain: relevance of dry deposition in semi-arid Mediterranean regions, Env. Poll., 118, 2, 259-272, 2002.

Seidl, W., Brunnemann, G., Kins, L., Koehler, E., Reusswig, K., and Dlugi, R.: On the ionic composition of aerosol particles and related gas phase species at two sites during the SANA 2 campaign, Meteorologische Zeitschrift, 5, 257-268, 1996.

Seinfeld, J. H. and Pandis, S. N.: Atmospheric chemistry and physics, John Wiley \& Sons Inc, 1356, 1997.

Sievering, H.: Eddy flux and profile measurements of small particle dry-deposition velocity at the Boulder Atmospheric Observatory (BAO). In: Precipitation Scavenging, Dry Deposition and Resuspension, edited by Pruppacher, H. R., Semonin, R. G., and Slinn, W. G. N., Elsevier, Amsterdam, NL, 963-977, 1983.

Sievering, H.: Small-particle dry deposition under high wind speed conditions: eddy flux measurements at the Boulder Atmospheric Observatory, Atmos. Environ., 21, 2179-2185, 1987.

Slinn, W. G. N.: Prediction for particle deposition to vegetative canopies, Atmos. Environ., 16, 7, 1785-1794, 1982.

Sutton, M. A.: The surface/atmosphere exchange of ammonia, Ph.D. Thesis, University of Edinburgh, Edinburgh, 194, 1990.

Sutton, M. A., Schjorring, J. K., and Wyers, G. P.: Plant Atmosphere Exchange of Ammonia, Philosophical Transactions of the Royal Society of London Series a-Mathematical Physical and Engineering Sciences, 351, 1696, 261-276, 1995.

Sutton, M. A., Nemitz, E., Fowler, D., Wyers, G. P., Otjes, R., San Jose, R., Moreno, J., Schjoerring, J. K., Husted, S., Meixner, F. X., Ammann, C., Neftel, A., and Gut, A.: The EXAMINE Project: exchange of atmospheric ammonia with European ecosystems, In: Proceedings of Eurotrac '96, edited by Borrell, P. M., Borrell, P., Kelly, K., Cavitas, T., and Seiler, W., Computer Mechanics Publications, Southampton, Garmisch-Partenkirchen, 155-161, 1996.

Sutton, M. A., Burkhardt, J. K., Guerin, D., Nemitz, E., and Fowler, D.: Development of resistance models to describe measurements of bi-directional ammonia surface-atmosphere exchange, Atmos. Environ., 32, 3, 473-480, 1998.

Tanner, C. B. and Thurtell, G. W.: Anemoclinometer measurements of Reynolds stress and heat transport in the atmospheric surface layer, Report TR ECOM 66-G22-F, University of Wisconsin, Madison, 1969.

Van Oss, R., Duyzer, J., and Wyers, P.: The influence of gas-to- 
particle conversion on measurements of ammonia exchange over forest, Atmos. Environ., 32, 3, 465-471, 1998.

Vong, R. J., Vickers, D., and Covert, D. S.: Eddy correlation measurements of aerosol deposition to grass, Tellus Series B, 56, 2, 105-117, 2004.

Webb, E. K., Pearman, G. I., and Leuning, R.: Correction of flux measurements for density effects due to heat and water vapour transfer, Quarterly Journal of the Royal Meteorological Society, 106, 85-100, 1980.

Wesely, M. L., Cook, D. R., Hart, R. L., and Speer, R. E.: Measurements and parameterization of particulate sulfur dry deposition over grass, J. Geophys. Res.-Atmos., 90, 2131-2143, 1985.

Wexler, A. S. and Seinfeld, J. H.: The distribution of ammonium salts among size and composition dispersed aerosol, Atmos. Environ., 24A, 1231-1246, 1990.
Wexler, A. S. and Seinfeld, J. H.: Analysis of aerosol ammonium nitrate departures from equilibruim during SCAQS, Atmos. Environ., 26A, 579-591, 1992.

Wyers, G. P. and Duyzer, J. H.: Micrometeorological measurement of the dry deposition flux of sulphate and nitrate aerosols to coniferous forest, Atmos. Environ., 31, 3, 333-343, 1997.

Wyers, G. P. and Erisman, J. W.: Ammonia exchange over coniferous forest, Atmos. Environ., 32, 3, 441-451, 1998.

Zhang, Y., ten Brink, H. M., Slanina, J., and Wyers, G. P.: The influence of ammonium nitrate equilibrium on the measurement of exchange fluxes of ammonia and nitric acid, in: Acid Rain Research: Do we have enough Answers?, edited by Heij, G. J. and Erisman, J. W., Elsevier Science B.V., 103-112, 1995. 